\title{
An Evaluation of Money Market Fund Reform Proposals
}

\section{Citation}

Hanson, Samuel G., David S. Scharfstein, and Adi Sunderam. "An Evaluation of Money Market Fund Reform Proposals." IMF Economic Review (forthcoming).

\section{Published Version}

http://www.palgrave-journals.com/imfer/index.html

\section{Permanent link}

http://nrs.harvard.edu/urn-3:HUL.InstRepos:22836593

\section{Terms of Use}

This article was downloaded from Harvard University's DASH repository, and is made available under the terms and conditions applicable to Open Access Policy Articles, as set forth at http:// nrs.harvard.edu/urn-3:HUL.InstRepos:dash.current.terms-of-use\#OAP

\section{Share Your Story}

The Harvard community has made this article openly available.

Please share how this access benefits you. Submit a story.

Accessibility 


\title{
An Evaluation of Money Market Fund Reform Proposals
}

Authors:

Samuel G. Hanson, shanson@hbs.edu, Assistant Professor of Finance, Harvard Business School and Faculty Research Fellow of the NBER, USA.

David Scharfstein, dscharfstein@hbs.edu, Edmund Cogswell Converse Professor of Finance and Banking, Harvard Business School and Research Associate of the NBER, USA.

Adi Sunderam, asunderam@hbs.edu, Assistant Professor of Finance, Harvard Business School and Faculty Research Fellow of the NBER, USA

\begin{abstract}
U.S. money market mutual funds (MMFs) are an important source of dollar funding for global financial institutions, particularly those headquartered outside the U.S. MMFs proved to be a source of considerable instability during the financial crisis of 2007-2009, resulting in extraordinary government support to help stabilize the funding of global financial institutions. In light of the problems that emerged during the crisis, a number of MMF reforms have been proposed, which we analyze in this paper. We assume that the main goal of MMF reform is safeguarding global financial stability. In light of this goal, reforms should reduce the ex ante incentives for MMFs to take excessive risk and increase the ex post resilience of MMFs to system-wide runs. Our analysis suggests that requiring MMFs to have subordinated capital buffers could generate significant financial stability benefits. Subordinated capital provides MMFs with loss absorption capacity, lowering the probability that an MMF suffers losses large enough to trigger a run, and reduces incentives to take excessive risks. Other reform alternatives based on market forces, such as converting MMFs to a floating NAV, may be less effective in protecting financial stability. Our analysis sheds light on the fundamental tensions inherent in regulating the shadow banking system.
\end{abstract}




\title{
An Evaluation of Money Market Fund Reform Proposals*
}

\author{
Samuel G. Hanson \\ David S. Scharfstein \\ Adi Sunderam
}

Harvard University and NBER

July 2015

\begin{abstract}
U.S. money market mutual funds (MMFs) are an important source of dollar funding for global financial institutions, particularly those headquartered outside the U.S. MMFs proved to be a source of considerable instability during the financial crisis of 2007-2009, resulting in extraordinary government support to help stabilize the funding of global financial institutions. In light of the problems that emerged during the crisis, a number of MMF reforms have been proposed, which we analyze in this paper. We assume that the main goal of MMF reform is safeguarding global financial stability. In light of this goal, reforms should reduce the ex ante incentives for MMFs to take excessive risk and increase the ex post resilience of MMFs to system-wide runs. Our analysis suggests that requiring MMFs to have subordinated capital buffers could generate significant financial stability benefits. Subordinated capital provides MMFs with loss absorption capacity, lowering the probability that an MMF suffers losses large enough to trigger a run, and reduces incentives to take excessive risks. Other reform alternatives based on market forces, such as converting MMFs to a floating NAV, may be less effective in protecting financial stability. Our analysis sheds light on the fundamental tensions inherent in regulating the shadow banking system.
\end{abstract}

\footnotetext{
* Contact information: Samuel G. Hanson, shanson@hbs.edu; David S. Scharfstein, dscharfstein@hbs.edu; Adi Sunderam, asunderam@hbs.edu. We are grateful to Peter Crane for providing data. We thank Deborah Lucas and Patrick McCabe for helpful discussions of our paper, as well as seminar participants at the NBER Monetary Economics conference and the International Banking conference sponsored by the IMF and De Nederlandsche Bank.
} 


\section{Introduction}

The shadow banking system - the nexus of market-based short-term financing and securitization that has grown rapidly over the last 15 years - was at the heart of the recent global financial crisis. The crisis exposed important structural vulnerabilities in the system that have been the subject of regulatory debate ever since. The debate over money market mutual fund (MMF) reform in the US highlights two competing schools of regulatory thought. The first school argues that MMFs, and other parts of the shadow banking system, are essentially banks and should be regulated as such. The second school is averse to bringing MMFs under the bank regulatory umbrella, instead advocating for subjecting them more fully to market forces.

This paper evaluates the leading reform proposals to address the structural vulnerabilities of US money market mutual funds (MMFs), analyzing them in terms of this overarching debate. Three proposed alternatives for reform have received the most attention. The first is to subject MMFs more fully to market forces by requiring them to report floating net asset values (NAVs). The other two alternatives are more closely linked to typical bank regulation: requiring MMFs to have a $1 \%$ capital buffer combined with a "Minimum Balance at Risk" (MBR) provision whereby investors cannot immediately redeem all of their shares; or requiring MMFs to have a $3 \%$ subordinated capital buffer.

In evaluating these proposals, we assume that the primary objective of reform is safeguarding global financial stability while preserving the monetary services that MMFs provide to savers. Prime MMFs, which mainly invest in paper issued by financial institutions, were at the heart of financial instability in the aftermath of the Lehman bankruptcy. Because they function mainly as intermediaries between US savers and the global financial system, and provide a significant share of the dollar funding of global financial institutions headquartered outside the U.S., runs on prime MMFs could cause system-wide runs on global financial institutions and reduce their ability to fund their dollar assets. It follows that in order to protect the most vital functions of the global financial system - credit intermediation and payment services-MMF regulation should attempt to both reduce the ex ante incentives of MMFs to take excessive risks and increase the ex post ability of MMFs to absorb losses without setting off runs. Given the critical role that prime MMFs play in channeling funds to the global financial system, our analysis of reform proposals pertains to prime MMFs unless otherwise noted. 
We evaluate each of the reform alternatives in light of these objectives. Our analysis suggests that robust subordinated capital buffers could be effective in achieving these reform goals. ${ }^{1}$ Junior capital provides MMFs with loss absorption capacity, reducing the probability that a fund suffers losses large enough to trigger a run. Capital buffers also mean that there is an investor class that explicitly bears losses and has incentives to curb ex ante risk-taking. Of the reform proposals, only capital-based solutions reduce ex ante incentives for risk-taking. Capital-based solutions also maintain the current fixed NAV structure for ordinary MMF investors and thus preserve any transactional benefits those investors reap from the existing system.

In addition, we calibrate the required size of the junior capital buffer using a standard model of portfolio credit losses. The key input parameters are the probability that any given issuer defaults on short-term paper, the loss given default, the correlation in defaults across issuers, and the concentration of the MMF portfolio. For a well-diversified portfolio, we estimate that MMFs should hold a capital buffer of $3 \%$ to $4 \%$ against unsecured paper issued by global financial institutions, the primary asset held by MMFs. For more concentrated portfolios, we estimate that the amount of capital should be considerably higher. At a minimum, for an MMF to be able to survive a default by at least one portfolio firm, the buffer must be larger than the funds' maximum firm exposure.

We next turn to the Minimum Balance at Risk (MBR) proposal. In this proposal, investors are required to leave up to $3 \%$ of their funds in the MMF for 30-days after redeeming the rest. These "Minimum Balance Funds" become subordinated and take first loss should the MMF break the buck. Thus, the MBR is a form of junior capital, and could have some of the same benefits of the capital buffer proposal discussed above. However, MBR requires the most risk-averse moneymarket investors to provide this capital ex post. This potentially sacrifices some of the risk-sharing benefits that MMFs provide. In addition, the MBR may not discourage MMF shareholders from running to protect the remaining $97 \%$ of their investment in a crisis.

Finally, we turn to the floating NAV proposal. Floating NAVs could provide significant financial stability benefits. They could lead investors to understand that MMFs are risky, encouraging them to invest more cautiously. Moreover, floating NAVs could reduce the strategic motive for MMF shareholders to run in a crisis by reducing the benefit associated with early exit. However, our analysis also highlights three reasons these benefits may not be fully realized in

\footnotetext{
${ }^{1}$ Capital buffers were originally proposed in 2011 by the Squam Lake Group (2011), a non-partisan, non-affiliated group of academics who offer guidance on the reform of financial regulation.
} 
practice. First, floating NAV may not alter investors' incentive to chase risk. Evidence suggests that institutional investors understand the risks of MMFs and have proven willing to invest in risky funds because of their higher yield given that they also have the right to redeem their shares on demand. Second, because the paper held by MMFs is illiquid, moving to a floating NAV may not produce significant variation in reported NAVs-floating NAV MMFs could look very similar to today's stable NAV product. Third, in a crisis, incentives for investors to run before illiquid MMF assets have to be sold at a loss are likely to remain. Overall, our analysis suggests that requiring MMFs to adopt a floating NAV structure may be insufficient to address the instabilities associated with MMFs.

In July 2014, the SEC adopted several new rules regarding MMFS. Primary among these was a decision to require institutional prime and municipal funds to adopt a floating NAV structure. These new regulations are set to take effect in the second half of 2016. Our analysis of the floating NAV proposal points to potential limitations of this approach, suggesting that it is unlikely to meaningfully reduce the threat of a widespread run on MMFs.

The remainder of the paper is organized as follows. In the next section, we provide some background on money market funds. In Section III we discuss the market failures involving financial stability that motivate MMF reform. In Section IV we analyze junior capital buffer proposals as well as the MBR proposal, while Section V analyzes floating NAV proposals. Section VI considers alternative reform proposals, and Section VII offers some concluding remarks.

\section{Money Market Funds and Systemic Risk}

\section{A. Background on money market funds}

A money market fund is a type of mutual fund that is required by law to invest in short-term, low-risk securities. Money market funds in the US are regulated by the Securities and Exchange Commission (SEC) under Rule 2a-7 of the Investment Company Act of 1940. These funds are very low risk compared to most other mutual funds and typically pay dividends that reflect the level of short-term interest rates. Critically, unlike some deposit accounts at commercial banks, money market funds are not insured by the government.

Money market funds typically invest in short-term government securities, bank certificates of deposit, commercial paper issued by corporations, repurchase agreements, or other short-term, low-risk securities. MMFs attempt to keep their net asset value (NAV) at a constant $\$ 1.00$ per 
share - only the fund yield goes up and down. Specifically, the "penny rounding" provisions of Rule 2a-7 allow MMFs to report a $\$ 1.00$ net asset value as long as their "shadow NAV" has not fallen below $\$ 0.995$. However, an MMF's reported NAV may fall below $\$ 1.00$ - an event known as "breaking the buck"-if the shadow NAV falls below $\$ 0.995$.

According to data from the Investment Company Institute, US MMFs managed approximately $\$ 2.68$ trillion of assets as of February 2014. The bulk of these money fund assets, over $\$ 1.46$ trillion, are in "prime" money market funds, which invest in paper issued by private, non-government borrowers. The remaining money-fund assets are in government money market funds ( $\$ 0.95$ trillion), which invest in Treasury bills and other short-term US government obligations, and tax-exempt money market funds ( $\$ 0.27$ trillion), which invest in tax-exempt shortterm paper issued by states and municipalities.

Figure 1: Assets of Institutional and Retail Prime MMFs. This figure plots the total assets under management of institutional and retail prime US MMFs based on weekly data from the Investment Company Institute.

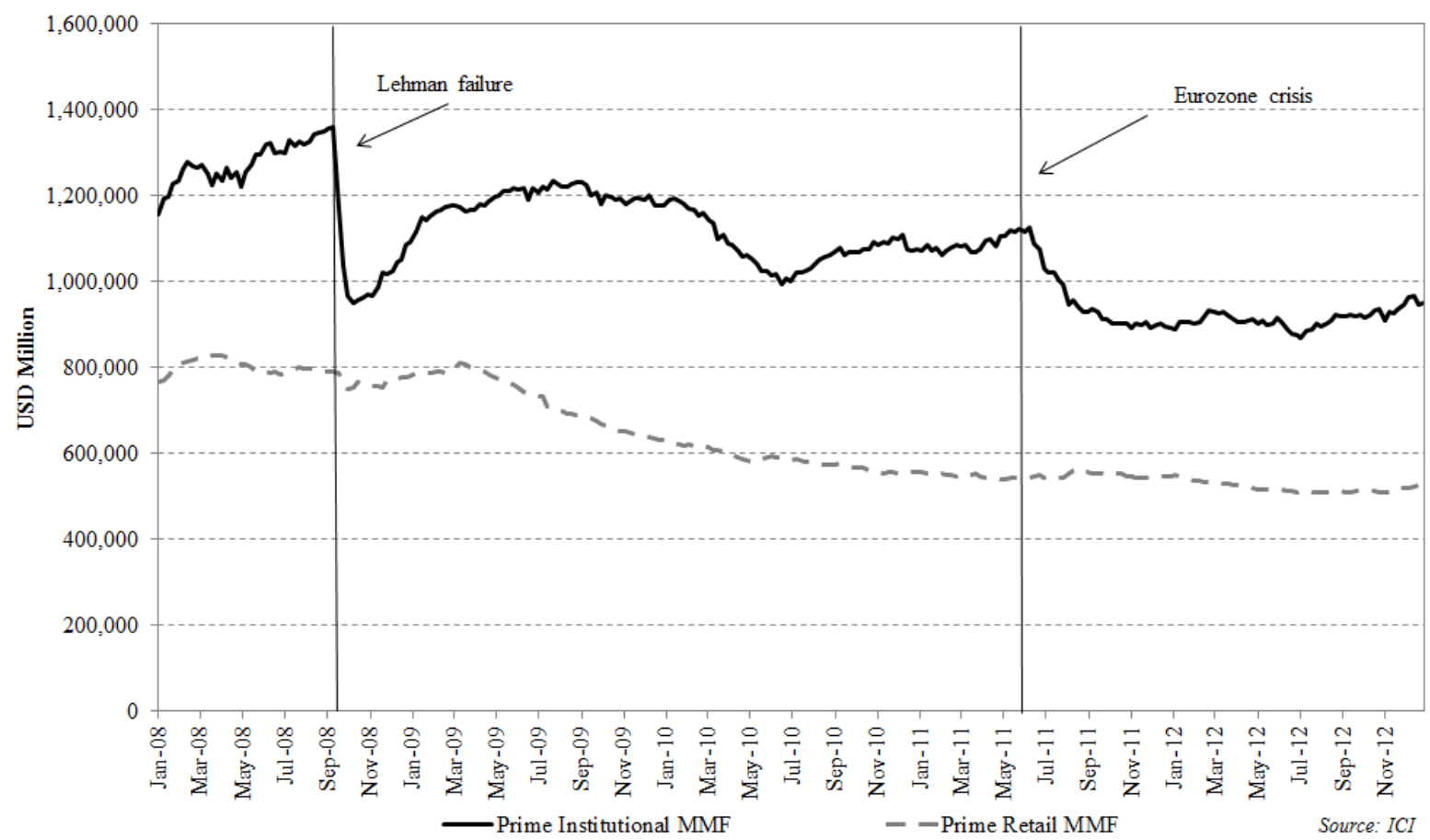

Figure 1 plots the assets under management of prime US MMFs from 2008 to present, broken out into institutional and retail funds. Institutional MMFs are high minimum investment, low expense share classes that are marketed to nonfinancial firms, governments, and institutional investors. Retail MMFs are low minimum investment, higher expense share classes that are marketed to households. Approximately $\$ 940$ billion of prime MMF assets are currently in 
institutional funds and the remaining $\$ 520$ billion are in retail funds. As Figure 1 clearly shows, the assets under management of institutional MMFs are far more volatile than the assets under management of retail funds, tending to fall sharply in times of system-wide financial stress.

\section{B. MMFs are a critical funding source for large, global banks}

Prime MMFs are a crucial source of short-term, wholesale dollar funding used by large global financial firms. A rough estimate is that prime MMFs provide $35 \%$ of such funding. ${ }^{2}$ Furthermore, prime MMFs mainly invest in money-market instruments issued by large, global banks - mostly in the form of commercial paper (CP), repo, and bank certificates of deposit (CDs).

Table 1 lists the 50 largest non-government issuers of money market instruments held by prime MMFs as of May 2012.

Table 1: List of Top-50 Non-Government Issuers in Prime MMF Portfolios, May 2012. The table is based on data from Crane Data. Total prime money market fund (MMF) assets were \$1,423 billion as of May 2012. Approximately $\$ 308$ billion of these prime MMF assets were invested in Treasuries, Agency securities, or municipal securities, with the remaining $\$ 1,111$ billion invested in non-government issuers.

\begin{tabular}{|c|c|c|c|c|c|}
\hline Issuer & $\begin{array}{l}\text { May 2012 } \\
\text { (USD } \\
\text { billions) }\end{array}$ & $\begin{array}{c}\text { Percent of } \\
\text { MMF } \\
\text { Assets }\end{array}$ & Issuer & $\begin{array}{l}\text { May 2012 } \\
\text { (USD } \\
\text { billions) }\end{array}$ & $\begin{array}{c}\text { Percent of } \\
\text { MMF } \\
\text { Assets }\end{array}$ \\
\hline 1 Barclays Bank & 56.8 & $3.99 \%$ & $26 \mathrm{HSBC}$ & $\mathbf{1 7 . 4}$ & $1.22 \%$ \\
\hline 2 Deutsche Bank AG & 52.1 & $3.66 \%$ & 27 DnB NOR Bank ASA & 15.8 & $1.11 \%$ \\
\hline 3 Bank of Tokyo-Mitsubishi UFJ Ltd & 45.4 & $3.19 \%$ & 28 BNP Paribas & 15.2 & $1.07 \%$ \\
\hline 4 Bank of Nova Scotia & 42.9 & $3.01 \%$ & 29 Skandinaviska Enskilda Banken AB & 14.5 & $1.02 \%$ \\
\hline 5 Sumitomo Mitsui Banking Co & 42.6 & $2.99 \%$ & 30 Canadian Imperial Bank of Commerce & 14.1 & $0.99 \%$ \\
\hline 6 National Australia Bank Ltd & 41.4 & $2.91 \%$ & 31 Australia \& New Zealand Banking Group Ltd & 13.7 & $0.96 \%$ \\
\hline 7 JP Morgan & 40.4 & $2.84 \%$ & 32 Credit Agricole & 13.4 & $0.94 \%$ \\
\hline 8 Credit Suisse & 40.2 & $2.82 \%$ & 33 Straight-A Funding LLC & 11.6 & $0.81 \%$ \\
\hline $9 \mathrm{RBC}$ & 37.8 & $2.66 \%$ & 34 FMS Wertmanagement & 11.4 & $0.80 \%$ \\
\hline 10 Rabobank & 37.6 & $2.65 \%$ & 35 ABN Amro Bank & 10.4 & $0.73 \%$ \\
\hline 11 Bank of America & 37.1 & $2.60 \%$ & 36 Norinchukin Bank & 10.3 & $0.72 \%$ \\
\hline 12 Westpac Banking Co & 28.9 & $2.03 \%$ & 37 Lloyds T SB Bank PLC & 9.6 & $0.68 \%$ \\
\hline 13 Citi & 28.5 & $2.00 \%$ & 38 Toyota Motor Credit & 9.2 & $0.64 \%$ \\
\hline 14 ING Bank & 25.8 & $1.81 \%$ & 39 State Street & 9.1 & $0.64 \%$ \\
\hline 15 Mizuho Corporate Bank Ltd & 25.7 & $1.81 \%$ & 40 Wells Fargo & 8.9 & $0.62 \%$ \\
\hline 16 RBS & 23.5 & $1.65 \%$ & 41 Natixis & 7.7 & $0.54 \%$ \\
\hline 17 General Electric Capital Corp. & 22.9 & $1.61 \%$ & 42 NRW.Bank & 6.6 & $0.46 \%$ \\
\hline 18 Bank of Montreal & 22.6 & $1.59 \%$ & 43 Morgan Stanley & 6.3 & $0.44 \%$ \\
\hline 19 Svenska Handelsbanken & 22.4 & $1.57 \%$ & 44 Nestle & 6.2 & $0.43 \%$ \\
\hline 20 Commonwealth Bank of Australia & 21.6 & $1.52 \%$ & 45 MetLife Insurance Company & 5.5 & $0.39 \%$ \\
\hline 21 Toronto-Dominion Bank & 20.9 & $1.47 \%$ & 46 US Bank & 5.2 & $0.36 \%$ \\
\hline 22 UBS AG & 20.1 & $1.41 \%$ & 47 Swedbank AB & 4.9 & $0.34 \%$ \\
\hline 23 Societe Generale & 19.6 & $1.38 \%$ & 48 Coca-Cola Co & 4.5 & $0.31 \%$ \\
\hline 24 Nordea Bank & 19.4 & $1.36 \%$ & 49 Branch Banking \& Trust Co & 4.3 & $0.30 \%$ \\
\hline 25 Goldman Sachs & 17.5 & $1.23 \%$ & 50 Oversea-Chinese Banking Co & 4.1 & $0.29 \%$ \\
\hline
\end{tabular}

These 50 issuers account for $73 \%$ of total prime MMF assets and $93 \%$ of assets not backed by the government. Of the top 50 issuers, only two are nonfinancial firms. $93 \%$ of the claims issued by the

\footnotetext{
${ }^{2}$ This estimate is based on data from the Flow of Funds. Specifically, we compute the fraction of large time deposits, repurchase agreements, and financial commercial paper held by MMFs. We estimate MMF financial commercial paper holdings as their total commercial paper holdings, scaled by the fraction of total commercial paper outstanding that is financial commercial paper (i.e., we assume that MMFs hold the "market portfolio" of commercial paper).
} 
top 50 issuers are claims on large global banks, of which $78 \%$ are claims on non-US banks. Altogether, only about 3\% of prime MMF assets are invested in paper issued by nonfinancial firms.

The importance of MMFs as a source of funding for global financial institutions has remained relatively stable since prior to the financial crisis. Figure $2 \mathrm{a}$ shows the value of MMF investments in foreign and US banks since June 2006, while Figure $2 \mathrm{~b}$ shows the percentage of MMF assets allocated to foreign and US banks. The figure shows that funding for US banks from MMFs declined in the aftermath of the financial crisis in 2008, but this decrease was offset by an increase in funding for foreign banks, primarily European banks. During the European sovereign debt crisis in 2011, MMFs decreased funding of European banks, but correspondingly increased their funding of Japanese and Australian banks.

As described by Shin (2012), the dollar liabilities of banks outside the US are substantial. According to data from the Bank of International Settlements, they were nearly $\$ 9$ trillion in 2010. As Figure 2a shows, over $\$ 1$ trillion of these liabilities were owed to US MMFs. The picture that emerges from Table 1 and Figure 2 is that US MMFs are significant providers of dollar funds to these banks, and have been since prior to the financial crisis.

Figure 2a: Levels. The figure is constructed using data from Fitch Ratings, which reports the asset allocation of the 10 largest MMFs. These MMFs comprise roughly 50\% of all US MMF assets. We then extrapolate their asset allocation to the overall US MMF industry, using data on assets under management for all prime MMFs from the Investment Company Institute.

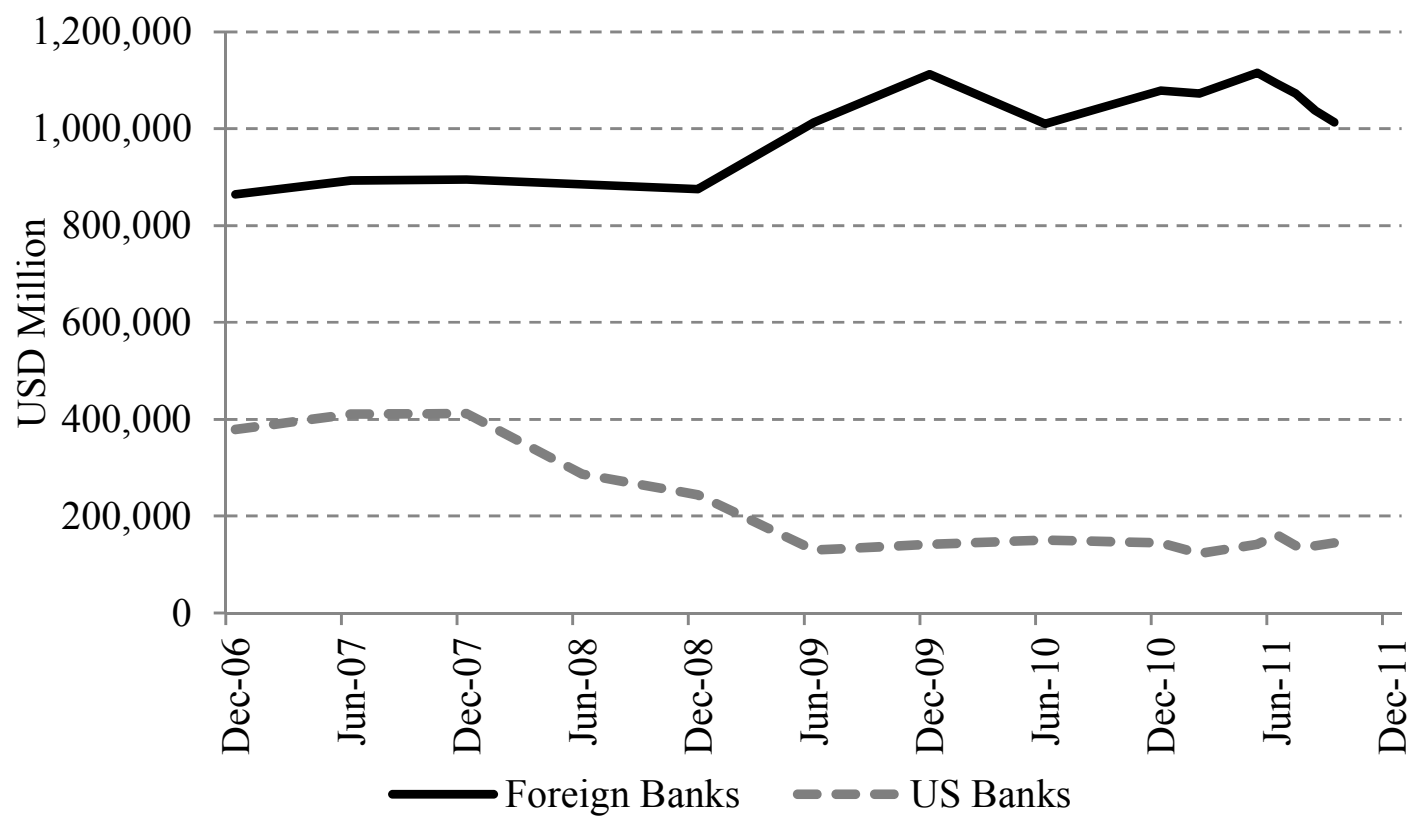


Figure 2b: Percentages. The figure is constructed using data from Fitch Ratings, which reports the asset allocation of the 10 largest MMFs. These MMFs comprise roughly 50\% of all US MMF assets. We then extrapolate their asset allocation to the overall US MMF industry, using data on assets under management for all prime MMFs from the Investment Company Institute.

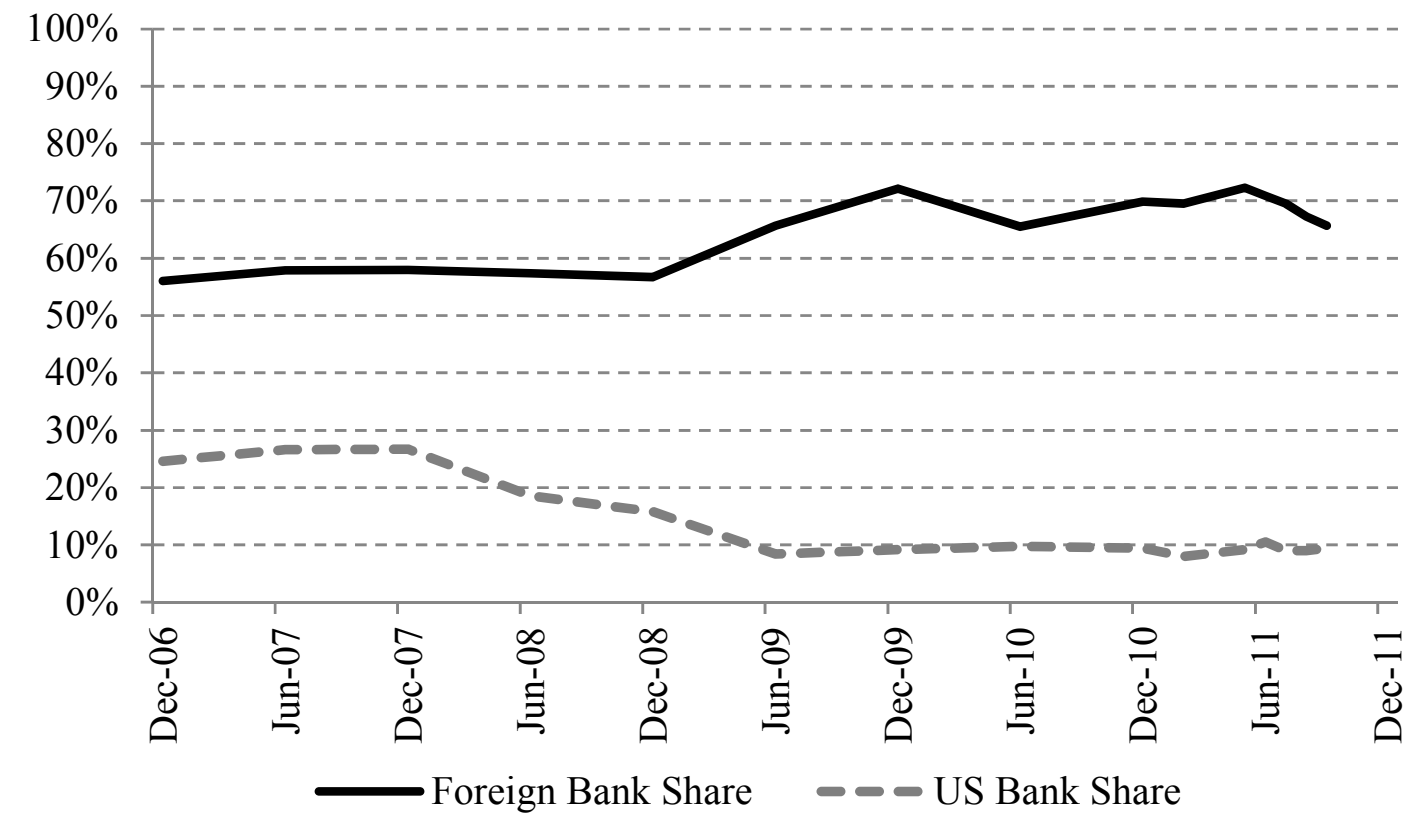

Thus, prime MMFs are essentially vehicles to collect dollar funds from US individuals and nonfinancial firms to provide financing to large global banks, particularly European banks, which in turn use the proceeds to make dollar loans. In other words, prime MMFs function like "correspondent banks" that take deposits and invest those funds in the deposits of other banks. Prime MMFs add a step in the chain of credit intermediation, since individuals and nonfinancial firms can and do directly invest in bank deposits and other short-term claims on financial institutions. The benefit of adding this link in the intermediation chain is that it provides MMF investors with a diversified pool of deposit-like instruments with the convenience of a single deposit-like account. Given the fixed costs of managing a portfolio of such instruments, MMFs provide scale efficiencies for small-balance savers (e.g., households and small- and mid-sized nonfinancial corporations) along with a set of transactional services (e.g., check-writing and other cash-management functions).

Set against these benefits are two potential costs related to the stability of the financial system. First, MMFs may undermine financial stability to the extent that they take excessive risk in their portfolios. Such risk-taking attracts yield-sensitive investors who may later run. Second, because MMFs allow investors to redeem their shares on demand, they are vulnerable to runs when 
investors become concerned about the risk of the assets in the funds. This, in turn, can induce a run by MMFs on the global financial institutions that they finance. We now discuss these two sources of instability in more detail.

\section{Incentives for MMF risk-taking}

There can be considerable credit risk in the portfolios of prime MMFs (Rosengren (2012)). For instance, as of September 30, 2011, almost 40\% of MMF holdings were backed by firms with a CDS spread above 200 basis points, far in excess of the average investment grade CDS spread of roughly 145 basis points. ${ }^{3}$ Nearly $5 \%$ of holdings were backed by firms with a CDS spread over 400 basis points. While these CDS spreads are for 5-year unsecured bonds-which tend to be riskier than the short-term and often secured instruments held by MMFs-these statistics underscore the fact that a significant fraction of the paper in prime MMFs was issued by relatively risky firms.

Why do funds hold money market instruments issued by such seemingly risky firms? Evidence from several studies shows that institutional investors reward MMFs for taking risk. MMFs with riskier portfolio holdings, and hence with higher yields, are normally rewarded by investors with inflows of assets. Specifically, so long as investors are not overly concerned about the health of the financial system, assets under management tend to grow faster for riskier funds. These studies show that institutional investors can be extremely yield-sensitive; they appear willing to move large sums between MMFs in order to gain as little as 10 basis points of yield (Kacperzyck and Schnabl (2013) and Chernenko and Sunderam (2013)). Institutional investors may seek out riskier MMFs with higher yields because they believe they can redeem their shares before bearing any losses associated with this risk-taking. But when investors protect themselves in this way, they can exacerbate stresses on MMFs. This could impair the ability of MMFs to provide financing to the banking sector and, consequently, to the real economy.

This yield-seeking behavior could be destabilizing because it induces MMFs to take on excessive risk precisely when there are early warning signs of future system-wide financial stress. For instance, during the early stages of the global financial crisis, MMFs that invested in risky asset-backed commercial paper were able to offer higher yields and grow their assets by close to 60\% from August 2007 to August 2008, while those that did not increase their yields saw little or no

\footnotetext{
${ }^{3}$ The CDX.IG CDS index, which includes 125 investment grade corporate bonds, had a 5-year CDS spread of 144 basis points on September 30, 2011.
} 
asset growth (Kacperzyck and Schnabl (2013)). Similarly, during the European sovereign debt crisis of 2011, yields on instruments issued by Eurozone banks increased. This created an opportunity for MMFs to grow their assets under management by purchasing the riskier, higher-yielding securities of Eurozone banks. Many MMFs again took advantage of this opportunity by taking on excessive portfolio risk (Chernenko and Sunderam (2013)).

In this way, MMF incentives to take risk when there are warnings of future system-wide stress may impede the orderly and healthy imposition of market discipline, whereby riskier banks are gradually deprived of funding at the early stages of a crisis. Instead, MMF's incentives for excessive risk-taking could raise the likelihood that market discipline is imposed in a disorderly fashion with sudden runs on risky banks at the late stages of a crisis.

\section{Systemic run risk}

MMFs may also exacerbate the risk of widespread runs on the broader global financial system. Since MMFs give investors demandable claims - they allow investors to redeem their shares on a daily basis - they can amplify run risk in the financial system.

There are two broad theories of runs. The first, pioneered by Diamond and Dybvig (1983), emphasizes strategic interactions between short-term creditors. The key insight is that runs happen in settings where each investor benefits from withdrawing earlier than other investors. Thus, the mere risk of a run can generate a run. In the context of MMFs, one impetus for a strategic run stems from Rule 2a-7, which allows MMFs to maintain a stable \$1.00 NAV per share using amortized cost accounting and "penny rounding." This enables investors to redeem their shares at a fixed $\$ 1.00$ share price even if the mark-to-market value is less than $\$ 1.00$ per share. The stable NAV feature creates incentives for investors to withdraw earlier than others before an MMF "breaks the buck" and can no longer allow redemptions at $\$ 1.00 .^{4}$

\footnotetext{
${ }^{4}$ Modern versions of the Diamond-Dyvbig model of runs recognize the role of uncertainty about bank asset values and the behavior of other short-term creditors. See Goldstein and Pauzner (2005) and Morris and Shin (2010). In these models, inefficient runs stem from a collective over-reaction by short-term creditors to bad interim news about asset values. Specifically, each short-term creditor receives a noisy interim signal about asset values. Runs can be generated for either fundamental reasons - because the news about asset values is sufficiently bad - or for strategic reasons because a short-term creditor fears that other creditors have received bad signals. The probability of a run can be characterized as a function of the properties of the bank's balance sheet and the signals. For instance, in Morris and Shin (2010), a bank is more likely to suffer a run (i.e., news of a smaller loss will trigger a run) when its assets are more illiquid or when it relies more on short-term funding and less on long-term, loss-absorbing capital. These intuitions apply directly to the context of MMFs: MMFs with less capital and more illiquid assets are more likely to face inefficient runs. Moreover, the probability of inefficient runs in this context is increased by the fact that MMF investors
} 
Another impetus for Diamond-Dybvig style runs stems from the fact that the nongovernment assets (e.g., commercial paper and bank certificates of deposits) of prime money market funds are quite illiquid (Covitz and Downing (2007)). MMFs forced to liquidate such assets may have to sell them at heavily discounted, "fire-sale" prices. This creates run risk because early investor redemptions can be met with the sale of liquid short-term government debt, which generate enough cash to fully pay early redeemers. In contrast, late redemptions force the sale of illiquid assets at discounted prices, which may not generate enough cash to fully repay late redeemers. Thus, each investor benefits from redeeming earlier than others, setting the stage for runs. ${ }^{5}$ Indeed, during the financial crisis, the Federal Reserve set up the Asset-Backed Commercial Paper Money Market Mutual Fund Liquidity Facility (AMLF) to address this illiquidity problem (Duygan-Bump, et. al. (2013)).

The second broad theory of runs emphasizes the panic that can occur when "safe proves risky"-i.e., when highly risk-averse investors realize that they may suffer losses on assets they had previously regarded as "safe." This view highlights the special role of money-like assets that are perceived as being absolutely safe stores of value. According to this view, risk-averse investors treat assets that are classified as "safe" in a qualitatively different way than they treat assets that are classified as "slightly risky." As a result, panic-driven runs can occur when investors reclassify an asset from "safe" to "slightly risky." This mechanism naturally generates runs on MMFs, which are designed to be regarded as "safe" by investors in normal times. However, in times of financial stress, investors can quickly change their opinions if an MMF suffers losses, or has portfolio holdings that expose it to significant risk of loss. ${ }^{6}$

Although a full review of the evidence is beyond the scope of this paper, our reading of the evidence on bank runs by depositors and the more recent runs by short-term creditors suggests that

only do limited research on the credit quality of the MMF portfolio, making the interim signals they receive relatively noisy.

${ }^{5}$ Chen, Goldstein, and Jiang (2010) present a model of runs by mutual fund investors based on the idea that, when there is a negative shock to asset values, shareholders have an incentive to redeem their shares before illiquid assets have to be sold at fire sale prices. Consistent with this theory, they show that fund outflows are more sensitive to poor performance in equity mutual funds if the assets of the fund are more illiquid. Also, consistent with the theory, Manconi, Massa, and Yasuda (2012), show that mutual funds sell their more liquid securities before selling their less liquid securities in response to shareholder redemptions.

${ }^{6}$ According to one version of this view, investors sometime neglect the possibility of certain rare events and mistakenly classify assets that are slightly risky as riskless (Gennaioli, Shleifer, and Vishny (2012)). Significant dislocations ensue when investors realize these assets are risky, leading them to run for the exits. A second version argues that investors have a special demand for safe, liquid assets that function as a medium of exchange and that such "money-like" assets command a premium. In this telling, assets quickly lose this premium once they become slightly risky (Stein (2012)). 
both the strategic view of runs and the panic-based view capture important aspects of reality. Thus, an optimal policy should work under either model of runs.

Runs are not only damaging to a particular MMF but are likely to have negative impacts on the global financial system and the real economy. A run at one MMF could precipitate runs on other MMFs if, as one might expect, investors are concerned that the factors leading to losses in one fund could affect other funds. In this case, many MMFs may become reluctant to roll over the securities in their portfolios, amplifying the funding stresses on financial institutions. As a result, an otherwise healthy bank might face funding difficulties because the failure of another bank leads to a run on the MMF sector. In this way, a widespread run on MMFs could destabilize the broader financial system, potentially triggering a credit crunch that would spill over into the real economy.

Systemic MMF runs have occurred twice in the past four years. When the Primary Reserve Fund "broke the buck" on September 16, 2008 after the failure of Lehman Brothers, it precipitated a massive run on prime MMFs, mainly by institutional investors who were concerned about MMF exposures to troubled financial firms. As illustrated in Figure 1 above, assets in institutional prime MMFs fell by 29\% within just two weeks of Lehman's failure. Because large financial firms depend heavily on MMFs for short-term funding, the run on MMFs generated significant additional stresses on the financial system at the peak of the crisis. The run would likely have been far more severe had the Treasury not temporarily guaranteed MMF balances on September 19, 2008. Even with these guarantees in place, the Federal Reserve was forced to significantly expand its suite of emergency liquidity facilities to alleviate the resulting funding pressures on financial firms. ${ }^{7}$ In the absence of these extraordinary interventions, it is conceivable that the run on MMFs could have resulted in a cascading wave of intermediary defaults and a system-wide financial collapse.

Figure 1 also shows that a similar, but less extreme, episode took place in the summer of 2011 as investors in institutional prime MMFs became concerned about the exposure of European banks to the debt of struggling Eurozone sovereigns. Given the large presence of Eurozone banks in MMF portfolios, this led to a 20\% decline in institutional prime MMF assets from May 2011 to

\footnotetext{
${ }^{7}$ In September 2008, the Fed significantly expanded the eligible set of collateral for the Primary Dealer Credit Facility (PDCF) to support the tri-party repo market following the withdrawals of MMF repo funding. PDCF borrowing by broker-dealers reached over $\$ 140$ billion in October 2008. In September 2008, the Fed also introduced the AssetBacked Commercial Paper Money Market Mutual Fund Liquidity Facility (AMLF) to finance purchases of asset-backed commercial paper (ABCP) from MMFs facing significant investor redemptions. In October 2008, the Fed introduced the Commercial Paper Funding Facility (CPFF) which eventually funded over $\$ 350$ billion of commercial paper purchases, almost exclusively from financial firms.
} 
September 2011. These MMF outflows added to the stresses on Eurozone banks, particularly on their ability to fund their dollar loans both in the US and abroad. Indeed, recent studies show that European banks that were particularly dependent on MMFs for funding cut their lending in the US significantly relative to their lending in Europe (Ivashina, Scharfstein and Stein (2013); Correa, Sapriza and Zlate (2012)). Relatedly, Chernenko and Sunderam (2013) show that MMFs with larger exposure to Eurozone banks suffered larger outflows in 2011 and that this had significant spillovers: other issuers relying on these MMFs were also forced to reduce their short-term debt financing.

In summary, the evidence suggests that runs on MMFs have significant effects on the financial firms who borrow from them, ultimately disrupting the flow of credit to households and nonfinancial firms. Furthermore, given the heavy reliance of foreign and particularly European banks on MMFs for wholesale dollar funding, the potential of a run on US MMFs is an important threat to both domestic and global financial stability.

\section{The Goals of Structural MMF Reform}

\section{A. Goals of structural reform}

Before proceeding with our analysis of MMF reform proposals, it is important to be precise about the basis on which we are evaluating these reform proposals. The goal of regulation is to address well-defined market failures that private actors are unable to address themselves. In the context of the regulation of shadow banking, we work from the premise that the principal market failures involve financial stability since there is no market that enables private actors to purchase access to a stable financial system. However, the actions of individual financial actors can be systemically destabilizing, imposing externalities upon others. Sound "macro-prudential" financial regulations help to correct these market failures, discouraging individual financial actors from taking systemically destabilizing actions that may be in their private interest but harmful to the financial system and the economy as a whole (Hanson, Kashyap and Stein (2011)).

The financial stability concerns we discuss above primarily stem from the relationship between prime MMFs and the global financial system, so our analysis of proposals focuses on prime MMFs. What are the potential market failures that MMF reform might correct?

1) MMF investors can withdraw funds on demand. The fact that MMF investors can redeem their funds immediately gives them strong protections if the MMF gets in 
trouble. However, it also means that the full economic costs of MMF risk-taking and runs may not be borne by MMF investors in isolation. Some of these costs can be borne by other parts of the financial system and economy. Specifically, runs on MMFs may destabilize the financial system and trigger a broader credit crunch. The existence of these external costs could make MMF investors more willing to invest in risky MMFs ex ante and more willing to run ex post than if they fully internalized these costs.

2) Implicit government guarantees. Given the turmoil that roiled global money markets following the failure of Lehman Brothers in September 2008 and the ensuing run on prime MMFs, investors may expect future policymakers to intervene to stabilize MMFs (or to stabilize money markets more broadly) if MMFs ever again faced a large-scale run. The expectation of future taxpayer support - implicit government guarantees, which are provided to MMFs free of charge - could encourage MMF managers and investors to take on excessive risk ex ante. ${ }^{8}$

3) Spillovers across funds. Since many MMF investors are relatively uninformed and have limited resources to process information about individual funds, trouble at one MMF may rapidly precipitate runs on other MMFs. However, an individual fund will rationally ignore the spillover costs of its own risk-taking on the stability of other funds and, hence, the stability of the financial system as a whole.

4) Excessive short-term funding of financial firms. The three market failures listed above could lead to excessive risk-taking by MMFs. This in turn means that financial firms, which dominate MMF portfolios, may be able to obtain short-term funding below its true economic cost. Financial firms are likely to respond to these lower costs by relying too heavily on short-term financing, which may result in significant spillovers to the rest of the financial system and economy when there is a run on short-term funding.

Given these market failures, and the objective of making the financial system more stable, reforms should aim to reduce the probability and impact of a large-scale run on prime MMFs. This broad objective can be refined into four more concrete goals. Below we evaluate the various policy

\footnotetext{
${ }^{8}$ After the failure of Lehman Brothers and the run on MMFs, the U.S. Treasury Department guaranteed MMFs using the Exchange Stabilization Fund. As part of the legislation authorizing the Troubled Asset Relief Program, Congress included a prohibition against using the Exchange Stabilization Fund for such guarantees. Of course, this does not prevent the government from finding other ways to support MMFs or from changing the law.
} 
proposals - capital, floating NAV, and alternative policy proposals - based on the extent to which they help achieve these goals:

Goal 1: Reduce the incentive of MMFs to take on excessive portfolio risk ex ante.

Goal 2: Reduce the incentive for MMF investors to run ex post.

Goal 3: Reduce the impact of a MMF run on the global financial system and economy if a MMF run does occur.

Goal 4: Reduce the incentive for large financial institutions to rely excessively on unstable, short-term funding from MMFs. ${ }^{9}$

\section{B. Prior reforms}

Before laying out proposals for structural MMF reform, we first discuss some of the regulatory reforms that have recently been taken that directly or indirectly affect MMFs, including the 2010 SEC amendments to Rule 2a-7, the passage of the Dodd-Frank Act of 2010, the Basel III bank liquidity requirements that were proposed in 2010, and the 2014 SEC reforms. Our analysis of these recent reforms, a mix of bank-like and market-forces based reforms, suggests that further structural MMF reforms are needed to properly safeguard financial stability.

\section{B.1 2010 changes to Rule $2 a-7$}

In 2010, the SEC amended Rule 2a-7 as a first step towards reforming MMFs. The amendments included stricter portfolio quality restrictions, reduced reliance on credit rating agencies, stricter maturity limits, larger liquidity buffers, and enhanced disclosure standards.

These reforms may not unambiguously promote financial stability for two reasons. First, enhanced MMF liquidity buffers may increase the demand for short-term paper issued by large global financial institutions. As a result, they could work against policymakers' broader macroprudential goal of encouraging these financial institutions to reduce their reliance on unstable, shortterm funding. ${ }^{10}$ Thus, even though this rule may reduce the likelihood and impact of a run on

\footnotetext{
${ }^{9}$ As explained below, this would only fit within the overall objective for MMF reform to the extent that market failures associated with MMFs lead the market cost of short-term funding to fall below its social cost.

${ }^{10}$ While these rules encourage MMFs to hold shorter-term paper, other regulatory initiatives have been encouraging large financial institutions to rely less heavily on short-term debt. These conflicting policies invite regulatory arbitrage. Indeed, at least one dealer created an investment vehicle that issues very short-term commercial paper to MMFs which
} 
MMFs, it may make the financial system as a whole less safe. Second, as we discuss in greater detail in Section VI, optional gating (i.e., redemption restrictions) could exacerbate runs if investors fear that once the gates go down they will not have access to their money in the fund.

\section{B.2 The Dodd-Frank Act of 2010}

Orderly Liquidation Authority (OLA) contained in Title II of the Dodd-Frank Act gives the FDIC authority to resolve financially distressed financial institutions, such as broker-dealers, not otherwise governed by FDIC resolution procedures. The implementation of OLA may effectively protect the short-term creditors of US Systematically Important Financial Institutions (SIFIs) even if they are unsecured. This would provide some degree of protection to money market fund investors in SIFIs, thereby reducing the need for further MMF reform. ${ }^{11}$ However, as shown in Table 1, MMFs hold large amounts of paper issued by non-US global banks, which are not subject to OLA, and therefore put MMFs at risk of loss. Moreover, given that OLA has never been exercised, and requires separate determinations by the Treasury Secretary and the boards of the Federal Reserve and FDIC to be exercised, there could be significant uncertainty about whether it would be exercised and whether policymakers would in fact protect all short-term claims of a SIFI. This uncertainly could lead MMF investors to run.

\section{B.3 Basel III liquidity regulation}

One of the Basel III reforms attempts to make large, global financial institutions less vulnerable to runs by requiring them to hold more liquid assets and to issue less short-term debt. It has been argued that these regulations alone would be sufficient to reduce financial firms' overreliance on unstable, short-term funding so that structural MMF reforms are unnecessary. ${ }^{12}$ In the absence of market distortions associated with MMFs, bank liquidity regulations would arguably be sufficient to safeguard financial stability. Bank liquidity regulations are useful since the supply

\footnotetext{
is then invested in slightly longer-term financial paper (specifically, repurchase agreements). While this meets the regulatory requirements of both regulators, it does not make the financial system any safer.

${ }_{11}^{11}$ See Gruenberg (2012). As currently contemplated, the FDIC's "single point of entry" resolution strategy would protect the short-term claimants of financial operating companies-regulated commercial banks and broker dealerswhile imposing losses on the long-term unsecured creditors of financial holding companies. Thus, to the extent that MMFs hold short-term claims issued by regulated operating companies, OLA would tend to protect MMF investors.

${ }^{12}$ The Basel III liquidity regulations come in two parts. First, the Liquidity Coverage Ratio requires a bank to hold enough high-quality, liquid assets that can be converted into cash to meet its needs over a severe 30-day liquidity stress scenario specified by regulators. Second, the Net Stable Funding Ratio establishes a minimum amount of stable funding based on the liquidity characteristics of a bank's assets, with the aim of limiting "over-reliance on short-term wholesale funding during times of buoyant market liquidity.” See Basel Committee on Banking Supervision (2010).
} 
response of financial firms - who face a well-founded demand for truly riskless, money-like paper-is likely to be excessive from a system-wide point of view. ${ }^{13}$ However, market failures associated with prime MMFs (e.g., implicit government insurance) create excessive demand for the short-term paper of financial institutions, creating stronger incentives for large financial firms to circumvent the Basel III liquidity regulations. In this case, it would be desirable to pursue both Basel III liquidity regulations and further MMF reform.

\section{B.4 2014 SEC Reforms}

In July 2014, the SEC decided to require institutional prime and municipal funds to adopt a floating NAV structure. Treasury and government institutional funds were exempted, as were all retail funds. In addition, for all funds except Treasury and government funds, MMF sponsors would be allowed to prevent redemptions if liquid assets fell below certain thresholds, and could impose redemption fees if liquid assets fell below certain thresholds. These new regulations are set to take effect in the second half of 2016.

\section{Structural MMF reforms}

Fund sponsors, industry groups, government agencies, and academics have proposed a variety of structural MMF reforms. The alternatives fall into three broad categories:

1) Capital Buffers: These proposals would require MMFs to have some loss-bearing, subordinated capital like traditional banks.

2) Floating NAV: These proposals would require MMFs to publish market-based net asset values and to allow investors to redeem their shares at this "floating" NAV every day, just as all other mutual funds currently do.

3) Other measures:

a. Increased transparency: These proposals would require MMFs to disclose information on their portfolio holdings more frequently and in greater detail than is currently required under Rule $2 \mathrm{a}-7$.

\footnotetext{
${ }^{13}$ This is because individual financial firms take the probability and severity of liquidity-induced financial crises as given. By contrast, policymakers can take into account that the probability and severity of crises are not given, but instead depend on the aggregate liquidity/maturity mismatch of the financial system. See Stein (2012).
} 
b. Gating rules: These proposals would impose fees or restrictions on investor redemptions under certain conditions (e.g., in times of crisis).

The remainder of the paper explains the main alternatives and evaluates them in light of the reform goals discussed above.

\section{Subordinate Capital Buffers for MMFs}

We begin with the junior capital buffer proposal. Capital buffers could be achieved using a variety of different contractual mechanisms. The basic idea of all of these alternatives is that each $\$ 1$ of ordinary MMF shares would effectively be backed by more than $\$ 1$ of assets. Since ordinary MMF shares would effectively be over-collateralized, the MMF could suffer credit losses on some portfolio assets without ordinary MMF shareholders suffering a loss. In Appendix A, we discuss the mechanics of several different proposed versions of capital buffers, including a subordinated share class, a standby liquidity facility backed by a dedicated pool of US Treasuries, or a standby support agreement from a highly-rated financial institution. Conceptually, the key to all the proposals is that capital simply divides the risks and rewards of MMF portfolio assets between two distinct securities: a subordinated capital security which bears first loss and ordinary, senior MMF shares. The ordinary MMF shares are protected from the risk of loss by the presence of the subordinated capital buffer. In return, the ordinary senior shares receive slightly lower yields in normal times, while the subordinated capital buffer earns higher returns in normal times.

In addition to describing the benefits and costs of such a reform, we calibrate the size of the buffer that would be required to achieve the policy goals described above. We estimate that a capital buffer in the range of $3 \%$ to $4 \%$ of risk-weighted assets for a well-diversified MMF portfolio is consistent with the policy goals outlined above. A capital buffer of this size would reduce the risk borne by ordinary MMF investors, lowering the yields they earn by about 5 bps.

\section{A. Benefits of subordinate capital buffers}

There are two potential benefits of capital: it reduces both the risk of runs and the incentive to take excessive risk. Because subordinate capital providers absorb first losses, capital buffers lower the chance that ordinary MMF investors suffer a loss, holding asset portfolio risk constant. If ordinary MMF investors run after experiencing a loss, or after observing investors in another MMF experience a loss, capital would reduce the probability of a system-wide run. Moreover, if an MMF 
has sustained a modest loss that has eroded some but not all of its subordinated capital, an ordinary MMF shareholder is still protected by the remaining junior capital, and thus may have less cause for concern - both that his shares will be impaired and that others will be concerned that their shares will be impaired. Thus, capital means that the risk of a run may be less likely to become a selffulfilling prophecy, in which investors strategically choose to run because they anticipate that others will run. Of course, capital will not stop a run once the run is already in progress-i.e., once the MMF suffers a crippling loss and capital has been wiped out. ${ }^{14}$

Capital buffers may also reduce the incentive of MMFs to take excessive risks ex ante, and thereby precipitate a run when poor outcomes are later realized. If the fund sponsor provides capital directly and bears first loss, it has a direct incentive to reduce risk. Alternatively, if capital is provided by the market through the issuance of subordinate shares, then there is an indirect incentive to reduce risk, as subordinated shareholders could require higher yields to bear first loss on a riskier pool of assets. This, in turn, lowers the yield that can be offered to ordinary MMF investors. Thus, the strategy of increasing risk with the goal of increasing yields and attracting assets may be less effective when there are subordinate capital buffers.

Recent research by Kacperzyck and Schnabl (2013) supports the idea that junior capital can serve as a check on MMF risk-taking. In particular, large sponsors that offer a wide array of financial products in addition to MMFs (e.g., large mutual fund complexes or large banking firms) have historically been willing to support troubled MMFs in order avoid the broader reputational loss that might arise if their MMF broke the buck. These sponsors attempt to limit MMF risk-taking because their own capital-in the form of both financial resources and the franchise value of their other businesses-is at risk.

\section{B. Sizing MMF capital requirements}

The benefits of capital discussed above clearly depend on buffers being large enough to protect ordinary MMF investors in most states of the world. How large would the buffer need to be to achieve this goal? One approach to answering this question is to use the Vasicek (2002) model of portfolio credit losses. This procedure, which underlies the Basel II bank capital framework and is

\footnotetext{
${ }^{14}$ However, this does not imply that capital requirements cannot promote greater financial stability. By reducing the ex ante probability that investors suffer a major loss in the first place and weakening run incentives following modest MMF losses, capital may decrease the probability of system-wide runs. Using a global games framework, Morris and Shin (2010) show that increasing the amount of loss-absorbing capital on a financial intermediary's balance sheet reduces the probability of a strategic run by short-term creditors.
} 
explained in Appendix B, allows us to compute the amount of junior capital such that the unconditional probability of incurring portfolio losses large enough to exhaust the capital buffer and impair ordinary shareholders is only $0.1 \%$ per annum. As inputs, the model requires assumptions on the unconditional probability of default and loss given default for the typical issuer in an MMF portfolio, as well as the correlation between issuers. Given these inputs, we calculate the unconditional probability of realizing portfolio losses of various sizes and then find the amount of capital needed to protect ordinary, senior MMF shareholders from suffering any loss $99.9 \%$ of the time. The inputs used in our calibration are meant to capture the properties of highly-rated, nongovernment unsecured paper. The capital requirements our calibration delivers should be only applied to such assets. Secured exposures such as repo would receive lower capital charges, and holdings of government-backed assets could be exempted from capital requirements completely.

Our calibration suggests that a capital requirement in the range of $2 \%$ to $6 \%$ would be reasonable for a well-diversified portfolio of unsecured, nongovernment 2a-7 assets, with our preferred inputs yielding a capital requirement of 3\% to $4 \%$. A requirement of $3 \%$ to $4 \%$ for MMFs might initially seem surprisingly high given that banks' assets are far riskier than MMFs' and bank capital requirements are approximately 10\%. Two differences between bank and MMF portfolios explain the gap. First, loss given default is higher for issuers in MMF portfolios because they are largely global financial firms, which typically sustain larger losses in default than non-financial firms. Second, the correlations between issuers in MMF portfolios are higher because they are mostly financial firms, while banks tend to lend to a set of firms that is diversified across industries. ${ }^{15}$

While the calibration above is for a well-diversified portfolio, in practice many MMF portfolios are relatively concentrated. As in bank capital regulation, an MMF capital requirement could be augmented with a surcharge for undiversified portfolios. Thus, MMFs would face a schedule of capital buffers depending on their portfolio concentration. Appendix B provides estimates of the required surcharge for concentrated portfolios. Our estimates suggest that the

\footnotetext{
${ }^{15}$ Another approach to calibrating the capital requirement would be to study sponsor support events as in Brady, Anadu and Cooper, (2012). 78 of the 341 funds they studied received support in the financial crisis, and the average level of support for the 78 funds was 90 bps. With 90 bps of capital, roughly half (39) of the 78 funds would have still failed in the absence of sponsor support. The distribution of support events from this study implies that 3 to $4 \%$ capital would be sufficient to prevent failures in many but not all cases. However, note that the extent of sponsor support may be understated due to other government support of the money markets (CPFF, AMLF, the Treasury guarantee).
} 
surcharge consistent with the Basel II approach would be substantial for an equal-weighted portfolio of 25 private issuers - it could be as large as $4 \%$, for a total capital requirement of $8 \%$. However, the add-on would shrink rapidly and would be very small (only $0.10 \%$ ) for an equal-weighted portfolio of 75 issuers.

Such a system of concentration-dependent capital requirements would naturally create incentives for MMFs to reduce portfolio concentration. If such incentives successfully induced MMFs to reduce the concentration of their portfolios, this would facilitate their core objective of providing savers with a diversified portfolio of deposit-like instruments.

At the same time, it could be useful to couple these incentives discouraging portfolio concentration with an absolute concentration limit - a backstop similar to the Basel III leverage ratio that simply prevents MMF portfolios from becoming too concentrated. Overall, it is important for capital requirements and concentration limits to be set jointly. For instance, there is potential to reduce the amount of required capital by tightening the portfolio concentration limits on MMFs, which currently limit them to investing $5 \%$ of their assets in any one issuer. If the goal is for an MMF to be able to survive at least one portfolio default, then at a minimum the capital buffer must be larger than the concentration limit. ${ }^{16}$

Using our preferred parameter estimates, a 4\% capital buffer would reduce the probability that ordinary shareholders in a well-diversified MMF are impaired to the targeted $0.1 \%$ per annum. By contrast, under current rules, MMFs in some sense effectively have $0.5 \%$ capital because they only "break the buck" once they have losses exceeding 0.5\%. Ordinary shareholders in an MMF with only $0.5 \%$ capital have a $1.14 \%$ per year probability of being impaired.

\section{Drawbacks of capital}

One potential drawback of capital buffers is that subordinated MMF shares or standby liquidity facilities for MMFs could be expensive; the returns required to entice investors to hold a subordinated position would be so high as to significantly lower the yields on regular MMF shares. However, according to the logic of Modigliani and Miller (1958), this can only be the case if the underlying assets of MMFs are themselves risky. Since MMFs assets are typically thought to be quite safe, MMF capital, even in a first loss position, should also be safe and have a relatively low

\footnotetext{
${ }^{16}$ If the number of 2a-7-eligible issuers falls during downturns, the concentration of MMFs would rise, leading to an increase in capital requirements. In this way, concentration-dependent requirements might amplify negative shocks.
} 
required return. Our calibration exercise helps to clarify this point. It suggests that subordinate MMF shares would have default risk - i.e., the risk of a significant capital impairment - that is comparable to an A-rated or BBB-rated long-term bond issued by a financial firm. Appendix B details this calculation.

Intuitively, MMF capital is long term and cannot be withdrawn, while MMF portfolio assets are largely exposures to global financial firms. Thus, MMF capital essentially bears the long-term risk that any firm in the MMF portfolio defaults on its short-term paper. One way to see this is to consider an MMF that only invests in money market instruments issued by a single bank. While the equity holders in the bank are directly exposed to the risk of loss on the loans the bank makes-they are in a first loss position-MMF capital providers are only exposed to a loss after the bank's equity is completely wiped out. Thus, MMF capital is more comparable to long-term bank debt than to bank equity. Using this logic, current market data on long-term financial company debt suggests that a reasonable estimate of the spread that subordinated MMF shares would need to offer investors is in the range of $1.00 \%$ to $1.50 \%$ (i.e., 100 to 150 basis points) over default-free short-term government debt. This means the yield to the ordinary MMF shares would be reduced by 5 basis points $(=4 \% \times 125 \div 96 \%)$.

Of course, capital could be more costly in the presence of frictions in financial markets. The market for subordinated MMF shares could be relatively small at first with relatively few "natural buyers" for such securities. In that case, investors would demand a premium to buy this new product, raising the cost of capital beyond what risk alone would suggest. However, this extra cost may not have a noticeable impact on market participants. For instance, suppose this extra frictional cost is $100 \mathrm{bps}$. Assuming a 4\% capital requirement for MMFs, this mispricing would only raise the total cost of capital for MMFs by 4 bps (=4\% $\times 100 \mathrm{bps})$. The 4 bps would likely be shared by MMF investors and sponsors, as well as money market issuers.

Finally, like any system of capital requirements, MMF capital buffers have the potential to amplify shocks if they are applied without a macro-prudential focus. Specifically, it would be undesirable if individual MMFs reacted to a common negative shock by shrinking their assets in order to satisfy a fixed capital requirement. Instead, regulators should allow MMFs to temporarily operate with lower capital ratios and should encourage MMFs to recapitalize by raising new subordinated capital instead of by shedding assets (Hanson, Kashyap, and Stein (2009)). 


\section{Minimum Balance at Risk}

Researchers at the Federal Reserve Board and Federal Reserve Bank of New York have recently put forward a proposal for MMF reform, which they call "Minimum Balance at Risk" or MBR (McCabe, Cipriani, Holscher, and Martin (2013)). The basic idea is that some fraction of each investor's investment in a fund must serve as loss-bearing subordinate capital. The key innovation is that even if the investor redeems shares, that fraction of the initial investment must remain as subordinate capital in the fund for 30 days. One distinct advantage of the MBR proposal is that it has the potential to slow down a run that is already underway. As noted above, a subordinated capital buffer would be unlikely to discourage investors from withdrawing once a run has begun.

The MBR proposal effectively requires MMF investors to provide capital for the fund, and therefore has many of the positive attributes of capital buffers discussed above. In the MBR proposal, the capital is provided ex post by traditional MMF investors. In capital buffer proposals, the subordinated capital is provided ex ante by a different set of outside investors or by the fund sponsor. These differences may matter along two dimensions: (i) ex ante incentives for investor yield-chasing, and hence, MMF risk-taking and (ii) ex post reactions to losses.

Both capital buffers and MBR could help to reduce ex ante incentives for risk-taking because subordinated capital providers can exercise some degree of market discipline on fund managers. This is analogous to the idea that bank capital requirements reduce incentives for bank managers to take excessive risks because those risks are borne by bank equity holders. Evidence on the effectiveness of external market discipline from bank capital holders is mixed. ${ }^{17}$ So while market discipline from junior capital providers may not completely curb excessive risk-taking, it may play a useful role.

Under the MBR approach, incentives for ex ante risk-taking could be reduced in an additional way: investors would be directly discouraged from chasing yield across MMFs because they themselves would bear the losses generated by the resulting risk-taking. Furthermore, under the MBR approach, the operational costs of chasing yield across funds would increase because investors would be required to leave behind some subordinated capital when they transfer funds to another MMF. Thus, MBR might be expected to make investor balances more "sticky" in normal

\footnotetext{
${ }^{17}$ For instance, Gorton and Santomero (1990) find no relationship between the cost of capital and measures of bank risk taking, and Bliss and Flannery (2001) find that the cost of capital is correlated with measures of bank risk taking but do not affect the behavior of bank managers. In contrast, Ashcraft (2006) finds that the presence of subordinated debt has a positive effect on future bank outcomes.
} 
times. ${ }^{18}$ However, it is worth noting that by placing restrictions on ordinary MMF shareholders, MBR potentially reduces its transactional value to them. By contrast, capital buffers may not alter the transactional value to ordinary MMF shareholders. Specifically, firms and households who use MMFs as a safe store of value — i.e., for cash management—would have a very similar, albeit safer stable-value product.

A second difference between the two schemes concerns the ex post reaction of capital providers to losses. Under capital buffer proposals, the risk of loss would be primarily borne by more sophisticated, risk-tolerant investors who may be more likely to anticipate the possibility that their capital may be impaired in bad times. In contrast, under the MBR proposal, losses would be primarily borne by traditional MMF investors. These investors presumably choose to invest in MMFs because they are averse to bearing losses. Moreover, these highly risk-averse investors may be somewhat less sophisticated and may not fully anticipate the losses that the MBR mechanism could allocate to them in a crisis - particularly following a long period of financial market tranquility when it has been inoperative. Thus, it is possible that suddenly assigning losses to them in bad times could set off system-wide runs: the stability of the financial system is likely to be better protected by assigning losses to the least loss-averse investors, not the most loss-averse. In summary, MBR could potentially make MMFs more run-prone in bad times than a capital buffer regime.

Overall, however, capital buffer schemes and the MBR proposal are quite similar. While capital buffers more transparently allocate losses to more risk tolerant investors, the MBR proposal could also largely achieve the goals of MMF reform. Indeed, McCabe et. al. (2013) have proposed combining a more modest capital buffer with MBR with the goal of capturing the main benefits of each proposal.

\footnotetext{
18 In other words, the MBR would create switching costs that are likely to blunt competition between MMFs. While these costs are likely to discourage competition that may jeopardize financial stability (e.g., yield-chasing that encourages excessive risk taking), they may also blunt useful forms of competition (e.g., yield-chasing that encourages cost minimization by funds). Note, however, that these costs are somewhat akin to a transaction tax on MMFs - whether they are borne by investors or the MMFs themselves depends on elasticities of supply and demand. The analogy between MBR and a transaction tax is not exact because, under the MBR proposal, investors can redeem their retained shares after the 30 day retention period.
} 


\section{Floating NAV}

The floating NAV reform outlined by FSOC (2012) and put forth by the SEC (2013) would eliminate the so-called "penny rounding" provisions from Rule 2a-7, which allow MMFs to report their net asset value as $\$ 1.00$ so long as their shadow NAV has not fallen below $\$ 0.995$. Under such a proposal, MMFs would be required to disclose their exact net asset values each day, just as other mutual funds currently do. In addition, the recent FSOC proposal would multiply that share price by 100 and then round to the nearest penny, so, for instance, a fund with a shadow NAV of $\$ 0.9995$ and a reported price of $\$ 1.00$ under the current regime would instead report a price of $\$ 0.9995$. Under the SEC's 2013 proposal, government and retail MMFs would be exempt from this rule change, so only institutional prime MMFs would become subject to floating NAV accounting.

Our analysis of floating NAV proposals also has important implications for global wholesale funding vehicles that do not follow the US MMF regulations. For instance, many European MMFs have floating NAVs, ${ }^{19}$ as do many non-MMF cash management vehicles. Since our analysis suggests that floating NAV reforms may be ineffective in protecting global financial stability, it also suggest that wholesale funding vehicles outside of the US may require further regulation.

\section{A. Potential benefits of a floating $N A V$}

A floating NAV system potentially has three main benefits. First, a floating NAV could lower the probability of runs by reducing the strategic motive for runs. For example, consider an MMF that has two investors, each of whom owns shares with a face value of $\$ 1.00$. Under the stable NAV system, if the fund's true NAV declines to $\$ 0.997$, the investor who redeems first will receive $\$ 1.00$, while the investor who redeems second will receive only $\$ 0.994(=2 \times \$ 0.997-$ $\$ 1.00)$. Since redeeming first allows an investor to avoid losses, a stable NAV encourages investors to run. Thus, eliminating the stable NAV could eliminate the incentive for such strategic runs.

Second, a floating NAV could reduce the probability of panic-based runs. The stable $\$ 1.00$ NAV of MMFs encourages investors to believe that they are completely risk free, but under a floating NAV system, the argument goes, daily fluctuations in the reported NAV in normal times would lead investors to recognize the inherent riskiness of MMFs. Essentially, a floating NAV

\footnotetext{
${ }^{19}$ As explained by Gordon and Gandia (2013), European MMFs come in two varieties: stable NAV funds and accumulating NAV funds, whose NAV varies over time.
} 
would force risk-averse MMF investors to permanently reclassify MMF shares from "safe" to "slightly risky," thus making investors less likely to panic in a crisis.

Third, the floating NAV proposal could remove the government imprimatur of safety that MMFs currently enjoy, thus reducing the likelihood of future government support for MMFs and eliminating any implicit guarantees that may exist today. If realized, the combined impact of these benefits would achieve the main financial stability goals outlined in Section III.

\section{B. Drawbacks of a floating NAV}

The main drawback of the floating NAV proposal is that it may work in a similar fashion to the existing stable NAV system because secondary markets for commercial paper and other private money market assets such as CDs are highly illiquid. Therefore, the asset prices used to calculate the floating NAV would largely be accounting or model-based estimates, rather than prices based on secondary market transactions with sizable volumes. In this regard, MMFs are more similar to banks, which must make accounting-based assessments of loan portfolio value, than they are to equity mutual funds, which can easily mark their portfolios to market each day. ${ }^{20}$ Since such markto-model valuations would only adjust sluggishly, moving to a floating NAV system may not eliminate investor incentives to run in bad times. ${ }^{21}$

The illiquidity of secondary markets for private money-market instruments creates the possibility of fire sales and could give investors incentives to run, even under a floating NAV regime. In other words, run risk is not merely a matter of accounting, but rather stems from the combination of illiquid underlying assets and demandable shares (Diamond and Dybvig (1983)). MMFs can meet withdrawals by early redeemers by selling liquid assets such as Treasury bills. Once these liquid assets are exhausted, MMFs would be forced to meet subsequent redemptions by selling illiquid paper into the market, potentially at depressed, fire-sale prices. Other MMFs would then be forced to publish lower NAVs, which could lead to additional investor redemptions and

\footnotetext{
${ }^{20}$ Secondary markets for money-market instruments are likely to be most illiquid and valuation uncertainty is likely to be greatest when the global financial system is experiencing funding strains. For instance, in October 2008, in response to the extreme illiquidity of secondary markets for private money-market instruments, the SEC permitted MMFs to use amortized costs accounting even for the purposes of computing the shadow NAV (see ICI (2009) p. 65).

${ }^{21}$ Consider the above example of an MMF that has two investors, each of whose shares has an initial value of \$1.00. Suppose that under a floating NAV regime the fund announces that by accounting-based measures its NAV has declined to $\$ 0.997$, but the investors believe that the true economic NAV is only $\$ 0.990$. In this case, the investor who redeems first receives $\$ 0.997$, while the investor who redeems second receives only $\$ 0.983(=2 \times \$ 0.99-\$ 0.997)$.
} 
more forced sales. Anticipating this downward spiral, MMF investors may want to redeem their shares early in a crisis.

Indeed, the recent financial crisis witnessed widespread runs on MMF-like cashmanagement products with floating NAVs, including ultra-short bond funds in the US and variable NAV MMFs in Europe. ${ }^{22}$ For instance, Gordon and Gandia (2013) show that the stable versus variable NAV distinction among European MMFs explained none of the cross-sectional variation in withdrawal rates from European MMFs following the failure of Lehman Brothers in September 2008. Instead, withdrawals for both stable and variable NAV funds are related to measures of ex ante fund risk-taking and the likelihood of sponsor support.

These run incentives exist to some extent in all mutual funds holding illiquid assets but there are a few reasons to believe that the problem could be more severe with MMFs. First, strategic incentives to withdraw become more severe as the secondary market liquidity of the fund assets declines (Chen, Goldstein, and Jiang (2010)). MMF assets have less secondary market liquidity than the assets held by most other mutual funds, including equity funds and long-term bond funds. Moreover, since holdings are highly correlated across MMFs (McCabe et. al. (2013)), forced liquidations by a troubled MMF could potentially transmit distress to other MMFs. Thus, significant MMF outflows may be more likely to generate secondary fire sales, which in turn disrupt primary capital market activity, than runs on other types of mutual funds.

Second, money markets are characterized by a risk-averse investor base that may devote limited attention to monitoring and analyzing risks. Indeed, the fact that money-market investments typically require minimal monitoring is a key feature of these investments (Gorton and Pennachi (1990)). Thus, as compared to longer-term capital markets where monitoring is always necessary, money markets may be more fragile and prone to severe freezes when monitoring suddenly becomes necessary (Dang, and Holmstrom (2011); Hanson and Sunderam (2013)). Indeed, moving to a floating NAV may have the perverse effect of further reducing information production by giving allowing investors to free-ride on the information in the market price as in Grossman-Stiglitz

\footnotetext{
${ }^{22}$ Ultra-short bond funds are similar to MMFs in that they hold fixed-income securities with short maturities. However, the NAV of ultra-short bond funds floats. In August 2007, the NAVs on ultra-short bonds funds began to fall slowly and fund flows turned negative. Then in early March 2008, the NAV on all these funds dropped $2 \%$ and ultra-short bond funds experienced an outflow of $15 \%$ over the following month. Even though NAVs stabilized thereafter, moderate outflows continued throughout 2008, and by the end of 2008 assets of these funds were down more than $60 \%$ from their mid-2007 level (see Investment Company Institute (2009) p. 105).
} 
(1980). Rather than doing due diligence on a MMF's portfolio, investors may choose to simply rely on the floating NAV as indicator of the credit quality of its assets.

Third, runs on MMFs are likely to be more disruptive to the real economy than runs on other mutual funds because MMF assets are short-term liabilities of financial and nonfinancial firms. Firms rely on long-term credit markets and equity markets to finance large capital expenditures, and they have the option to temporarily delay capital expenditures when confronted with adverse equity and bond market conditions. However, firms rely on short-term credit markets to finance working capital needs that are necessary for their ongoing operations. Furthermore, financial intermediaries are heavily dependent on short-term credit markets and play a critical role in providing working capital finance to firms and short-term credit to households. Thus, disruptions to short-term credit markets may be more likely to have adverse effects on real activity than disruptions to long-term capital markets.

An additional drawback of floating NAV reform proposals is that the NAV may fluctuate little in normal times. ${ }^{23}$ As noted by the asset management firm, BlackRock (2012), "The NAV of these funds generally oscillates in a tight range of $+/-10$ bps around par for $99.9 \%$ of the time." That is, the share price would almost always be between $\$ 99.90$ and $\$ 100.10$. Thus, it is unclear that moving to a floating NAV regime would meaningfully alter investor perceptions about the risks inherent in MMFs. Specifically, investors could continue to treat floating NAV MMFs as "safe" in normal times and would quickly redeem their shares in a crisis when MMF were reclassified as "slightly risky", thereby destabilizing the financial system.

Moreover, floating NAV MMFs may still carry a significant government imprimatur of safety so long as Rule 2a-7 remains in effect. As currently contemplated (see FSOC (2012)), reform proposals would abolish the fixed NAV while maintaining all current Rule 2a-7 restrictions on the quality, maturity, and concentration of MMF holdings. Thus, Rule 2a-7 prime funds could still be considered a "government-certified safe product" so that allowing the NAV to float between $\$ 99.90$ and $\$ 100.10$ may not substantially change investor perceptions of risk and behavior. ${ }^{24}$

\footnotetext{
${ }^{23}$ Under the specific floating NAV proposal put forward in FSOC (2012), MMFs would be able use amortized cost accounting for short-term paper, which would further reduce the variation in posted NAVs. Rosengren et al (2013) argue that under a credible floating NAV proposal all MMF assets should be marked to market. Specifically, MMFs should be required to use the mark-to-market accounting practices currently used for computing the shadow NAV and should not be permitted to use to amortized cost accounting for short-term paper.

${ }^{24}$ A key part of the FSOC's (2012) floating NAV proposal was that sponsors would not be permitted to support their MMFs in order to stabilize the NAV. The SEC wisely chose to omit this provision from its 2013 proposal. If, as argued
} 
As mentioned above, the SEC's 2013 proposal would exempt all government MMFs and prime retail MMFs from the floating NAV provision. For government MMFs, this exemption is innocuous given the tremendous liquidity and safety of the underlying assets. However, this exemption may be questionable in the case of prime retail MMFs. While the behavior of institutional investors has been a major contributor to the recent instability of MMFs, the difference in behavior between retail and institutional investors may not be sufficiently permanent to serve as a basis for long-term policy. In particular, increases in the sophistication of retail investors, and improvements in the information technology available to them, may lead them to behave more like institutional investors over time. For instance, one explanation for the behavior of institutional investors is the availability of Internet portals that allow them to sort MMFs by yield and to easily transfer their cash to the highest-yielding funds. If such portals are made widely available to retail investors, their behavior may come to resemble the behavior of institutional investors. This argues for including both retail and institutional prime funds in reform efforts.

\section{Other Reform Proposals}

In this section, we briefly discuss two other MMF reform options.

\section{A. Increased transparency}

Another commonly proposed MMF reform is increased disclosure of fund portfolios. The main potential benefit of such reform is that increased disclosure could enable investors to more closely monitor fund risk-taking. In the event that the fund is taking too much risk, investors could then discipline the fund by redeeming their shares.

There are two main problems with such proposals. First, MMFs already publish a nearperfect measure of their risk-taking every day: the gross yield on their assets. Due to the strict limitations on portfolio risk dictated by Rule 2a-7, nearly all differences in gross yield across MMFs are due to differences in risk-taking. Unlike other types of mutual funds, there is virtually no scope for skilled managers to generate excess risk-adjusted returns through careful portfolio selection.

\footnotetext{
above, floating NAV MMFs are still subject to runs, sponsor support would continue to be an important line of defense protecting the system against cascading MMF runs. Moreover, if the sponsor were a banking firm, it could eventually be required by regulators to hold loss-absorbing capital against this implicit liability. However, to date, neither international bank capital standards nor their implementation in the US require sponsors to hold capital against these implicit exposures.
} 
Second, sophisticated institutional investors already monitor fund portfolios carefully. However, the behavior of institutional investors suggests that they want their MMFs to take risk because they believe they can redeem their shares before losses are realized in a crisis. Moreover, the SEC's 2010 enhancements to Rule 2a-7, which required funds to disclose their portfolio holdings monthly, have virtually done nothing to discourage this yield chasing behavior-investors rewarded MMFs that invested in risky Eurozone banks with inflows in early 2011, even though these transparency measures were in place.

\section{B. Liquidity fees and redemption gates}

A second set of commonly proposed MMF reforms are so-called gating rules. These proposals allow MMFs to operate as they currently do in normal times, but would impose redemption fees or restrictions on redemptions ("gates") if certain conditions are met. For instance, the SEC (2013) has proposed that investors pay a $2 \%$ liquidity fee on all redemptions once an MMF's 1-week liquidity level falls below 15\% (well below the current regulatory minimum of $30 \%)$. MMFs would also be allowed to temporarily suspend redemptions if this condition is met.

Such conditional restrictions could potentially help to discourage investor redemptions and control runs in the event of a crisis.

There are three main concerns about gating rules. First, gating rules have an inherently micro-prudential focus. They are based on the condition of individual funds and aim to control the behavior of investors in individual funds. However, gating rules can have significant macroprudential consequences. For instance, news that one MMF has initiated redemption restrictions could set off a system-wide run by panic-stricken investors who are anxious to redeem their shares before other funds also initiate restrictions. Furthermore, basing liquidity fees and the gating trigger on the fund's holdings of liquid assets discourages MMFs from drawing down on their buffers of liquid assets precisely when they should do so from a system-wide perspective, i.e., in a systemwide liquidity crisis. The purpose of maintaining buffers of liquid assets is to allow funds to meet large redemption requests without withdrawing financing from private issuers. In addition, liquidity-based triggers would encourage MMFs to keep their buffers of liquid assets very high to avoid concerns about triggering redemption fees or restrictions. This would increase their demand for very short-term instruments that qualify as liquid assets, e.g., paper maturing in five days or less. As a result, financial institutions would have greater incentives to fund themselves with very short 
term paper, making them more vulnerable to runs. This undermines the broader macroprudential goal of encouraging financial institutions to use longer-term, stable funding.

Second, Rule 2a-7 already contains a gating rule, which has proven to be ineffective. In particular, the fund may suspend redemptions if its NAV falls below \$0.995-i.e., if a fund "breaks the buck". This rule incentivizes investors to redeem their shares at the first indication of trouble out of fear that their cash could be trapped in the fund if it suspends redemptions. New gating rules will simply exacerbate the incentives for investors to redeem early by setting a threshold for redemption fees or restrictions closer to $\$ 1.00$ than the existing threshold of $\$ 0.995$.

Finally, in order for gating rules to be effective at mitigating a run once it has begun, they need to be stringent. However, stringent gating rules only amplify the ex ante incentives to withdraw early, before the gating rule is applied. For instance, suppose a fund's 1-week liquidity level is approaching the 15\% threshold under the SEC's (2013) liquidity fee scheme. Consider the problem of an investor who believes he will only receive $\$ 0.970$, the recovery value for investors in the Reserve Primary fund, if he leaves his money in the fund. This investor will redeem his shares unless he faces a liquidity fee of at least 3\%. However, if liquidity fees were set to $3 \%$ or more, this would exacerbate the early withdrawal problem. Knowing that he could face a future liquidity fee of $3 \%$, the investor would have strong incentives to redeem his shares long before the fund's 1-week liquidity level ever fell to $15 \%$.

\section{Conclusion}

The debate over money market mutual fund (MMF) reform in the US highlights two competing schools of thought regarding the regulation of the shadow banking system. If the primary objective of regulation is to safeguard the stability of the global financial system, reforms should be designed to curb ex ante incentives for excessive risk-taking and to bolster the ex post ability to absorb losses without setting off system-wide runs. Proponents of reform typically advocate for achieving these objectives through either bank-like regulations like capital requirements or marketbased regulations like the floating NAV proposal. For well-diversified funds, our analysis suggests that a capital buffer equal to $3 \%$ to $4 \%$ of risk-weighted assets could reduce the probability that ordinary MMF investors bear losses and would therefore reduce the risk of runs substantially. And, poorly diversified funds would need to have larger capital buffers to achieve these same benefits. Alternate reform proposals, including the floating NAV proposal that was adopted by the SEC in 
July 2014, may be less likely to significantly increase global financial stability. Overall, our analysis suggests that reforms based solely on market forces may not be sufficient to address the instabilities associated with MMFs and shadow banking more generally. Indeed, a related set of policy issues arise to varying degrees for mutual funds that hold illiquid assets (e.g., leverage loans and high yield bonds). These funds offer unlimited daily liquidity at a "zero-price-impact" NAV even though trades in the underlying have price impact. Thus, investors have a strategic incentive to withdraw to avoid bearing the price impact of others' withdrawals if they think others are likely to withdraw. Of course, the best policy prescriptions may be different since mutual fund investors presumably understand that these funds do fluctuate in value.

Finally, the risk of any regulation is that activities will migrate to less regulated parts of the financial system. For example, it is possible that that with enhanced regulation of MMFs, more assets will move to offshore dollar-denominated MMFs or to other cash management products. Regulators must be vigilant to guard against this possibility if money market reforms are to be effective. 


\section{References}

Altman, Edward I., and Vellore M. Kishore, 1996, "Almost Everything You Wanted to Know About Recoveries on Defaulted Bonds," Financial Analysts Journal, Vol. 52, No. 6 pp. 57-64.

Ashcraft, Adam, 2006, "Does the Market Discipline Banks? New Evidence from the Regulatory Capital Mix," Federal Reserve Bank of New York Staff Report No. 244 (New York, New York, Federal Reserve Bank).

Basel Committee on Banking Supervision, 2006, "International Convergence of Capital Measurement and Capital Standards."

Basel Committee on Banking Supervision, 2010, "Basel III: International Framework for Liquidity Risk Measurement, Standards and Monitoring."

Blackrock, 2012, "Money Market Funds: A Path Forward," BlackRock Viewpoint, September 27, 2012,

https:/www2.blackrock.com/webcore/litService/search/getDocument.seam?venue=PUB IND\&sou $\underline{\mathrm{rce}=\mathrm{GLOBAL} \& \text { contentId=1111173537. }}$.

Bliss, Robert R., and Mark J. Flannery, 2001, "Market Discipline in the Governance of U.S. Bank Holding Companies: Monitoring vs. Influencing," in Prudential Supervision: What Works and What Doesn't? ed. by F. S. Mishkin (Chicago and London. The University of Chicago Press).

Brady, Steffanie A., Ken E. Anadu, and Nathaniel R. Cooper, 2012, "The Stability of Prime Money Market Mutual Funds: Sponsor Support from 2007 to 2011," Risk and Policy Analysis Unit Working Paper No. RPA 12-3, (Boston, Massachusetts, Federal Reserve Bank of Boston).

Chen, Qi, Itay Goldstein, and Wei Jiang, 2010, "Payoff Complementarities and Financial Fragilities: Evidence from Mutual Fund Outflows," Journal of Financial Economics, Vol. 97, No. 2, pp. 239-62.

Chernenko, Sergey, and Adi Sunderam, 2014, "Frictions in Shadow Banking: Evidence from the Lending Behavior of Money Market Funds," Review of Financial Studies, Vol. 27, No. 6, pp. 171750 .

Correa, Ricardo, Horacio Sapriza, and Andrei Zlate, 2012, "Liquidity Shocks, Dollar Funding Costs, and the Bank Lending Channel During the European Sovereign Crisis," IFDP Paper No. 2012-1059, (Washington, DC, Federal Reserve Board).

Coval, Joshua D., Jakub W. Jurek, and Erik Stafford, 2009, "Economic Catastrophe Bonds," American Economic Review, Vol. 99, No. 3, pp. 628-66.

Covitz, Daniel, and Chris Downing, 2007, "Liquidity or Credit Risk? The Determinants of Very Short-Term Corporate Yield Spreads,” Journal of Finance, Vol. 62, No. 5, pp. 2303-28.

Dang, Tri Vi, Gary Gorton, and Bengt Holmstrom, 2010, "Opacity and the Optimality of Debt for Liquidity Provision," Working Paper.

Diamond, Douglas, and Philip Dybvig, 1983, "Bank Runs, Deposit Insurance, and Liquidity," Journal of Political Economy, Vol. 91, No. 3, pp. 401-19.

Duffie, Darrell, 2010, "The Failure Mechanics of Dealer Banks," Journal of Economic Perspectives, Vol. 24, No. 1, pp. 51-72 
Duygan-Bump, Burcu, Patrick Parkinson, Eric Rosengren, Gustavo Suarez, and Paul Willen, 2013, "How Effective Were the Federal Reserve Emergency Liquidity Facilities? Evidence from the Asset-Backed Commercial Paper Money Market Mutual Fund Liquidity Facility," Journal of Finance, Vol. 68, No.2, pp.715-37.

Gennaioli, Nicola, Andrei Shleifer, and Robert Vishny, 2012, "Neglected Risks, Financial Innovation, and Financial Fragility," Journal of Financial Economics, Vol. 104, No. 3, pp. 452-68.

Gordy, Michael, 2003, "A Risk-Factor Model Foundation for Ratings-Based Bank Capital Rules," Journal of Financial Intermediation, Vol. 12, No. 3, pp. 199-232.

Goldstein, Itay, and Ady Pauzner, 2005, "Demand-Deposit Contracts and the Probability of Bank Runs," Journal of Finance, Vol. 60, No. 3, pp 1293-1327.

Gorton, Gary, and George Pennacchi, 1990, "Financial Intermediaries and Liquidity Creation," Journal of Finance, Vol. 45, No. 1, pp. 49-71.

Gorton, Gary, and Anthony Santomero, 1990, "Market Discipline and Subordinated Bank Debt," Journal of Money, Credit, and Banking, Vol. 22, No. 1, pp. 119-28.

Grossman, Sanford, and Joseph Stiglitz, 1980, “On the Impossibility of Informationally Efficient Markets," American Economic Review, Vol. 70, No. 3, pp. 393-408.

Gruenberg, Martin, 2012, Speech given by the FDIC Chairman the Federal Reserve Bank of Chicago Bank Structure Conference, May 10, 2012. Available at: http://www.fdic.gov/news/news/speeches/chairman/spmay1012.html.

Financial Stability Oversight Council, 2012, "Proposed Recommendations Regarding Money Market Mutual Fund Reform," http://www.treasury.gov/initiatives/fsoc/Documents/ Proposed Recommendations Regarding Money Market Mutual Fund Reform - November 13, 2012.pdf.

Hanson, Samuel G., and Adi Sunderam, 2013 "Are There Too Many Safe Securities? Securitization and the Incentives for Information Production," Journal of Financial Economics, Vol. 108, No. 3, pp. 565-84.

Investment Company Institute, 2009, "Report of the Money Market Working Group.”

Ivashina, Victoria, David S. Scharfstein, and Jeremy C. Stein, 2015, "Dollar Funding and the Lending Behavior of Global Banks," Quarterly Journal of Economics, Vol. 130, No. 3, pp. 12411281.

Kacperczyk, Marcin, and Philipp Schnabl, 2013, “How Safe are Money Market Funds?” Quarterly Journal of Economics, Vol. 128, No. 3, pp. 1073-1122.

Manconi, Alberto, Massimo Massa, and Ayako Yasuda, 2012, "The Role of Institutional Investors in Propagating the Crisis of 2007-2009," Journal of Financial Economics, Vol. 104, No. 3, pp. 491518.

McCabe, Patrick, Marco Cipriani, Michael Holscher, and Antoine Martin, 2013, "The Minimum Balance at Risk: A Proposal to Mitigate the Systemic Risks Posed by Money Market Funds," Brookings Papers on Economic Activity, Spring 2013, pp. 211-78.

Modigliani, Franco, and Merton H. Miller, 1958, "The Cost of Capital, Corporation Finance and the Theory of Investment,” American Economic Review, Vol. 48, No. 3, pp. 261-97. 
Moody's Investors Service, 2010, "Special Comment: Default and Recovery Rates of Corporate Commercial Paper Issuers, 1972-2009.”

Moody's Investors Service, 2012, "Special Comment: Corporate Default and Recovery Rates, 1920-2011."

Morris, Stephen, and Hyun Song Shin, 2010, “Illiquidity Component of Credit Risk," Princeton University Working Paper (Princeton, New Jersey, Princeton University).

Rosengren, Eric, 2012, "Money Market Mutual Funds and Financial Stability": http://www.bos.frb.org/news/speeches/rosengren/2012/041112/041112.pdf.

Rosengren, Eric, et al, 2013, Letter to the Financial Stability Oversight Council, http://www.bostonfed.org/news/press/2013/pr021213-letter.pdf.

Securities and Exchange Commission, 2013, "Money Market Fund Reform," http://www.sec.gov/rules/proposed/2013/33-9408.pdf.

Shin, Hyun, 2012, "Global Banking Glut and Loan Risk Premium,” IMF Economic Review Vol. 60, No. 2, pp. 155-92.

Squam Lake Working Group, 2011, "Reforming Money Market Funds," http://www.squamlakegroup.org/Squam Lake MMF January 14 Final.pdf.

Stein, Jeremy C., 2012, "Monetary Policy as Financial-Stability Regulation," Quarterly Journal of Economics, Vol. 127, No. 1, pp. 57-95.

Vasicek, Oldrich, 2002, “Loan Portfolio Value.” Risk, December, pp. 160-62. 


\section{Appendix A: Contractual Mechanisms for Providing a Capital Buffer}

\section{A. Types of capital}

The capital buffer could be achieved using a variety of different contractual mechanisms. The basic idea of all of these alternatives is that each $\$ 1$ of MMF shares would effectively be backed by $\$(1+X)$ dollars of MMF assets. In other words, the MMF could suffer $\$ X$ of credit losses before ordinary MMF shareholders were forced to bear losses. Equivalently, each $\$ 1$ of assets would be financed by $\$ K=\$ X /(1+X)$ of first-loss subordinated capital and $\$(1-K)$ of ordinary, senior MMF shares.

Below we discuss several different contractual mechanisms for providing subordinated capital that have been proposed. All the variants provide the major benefits of capital discussed above, and all would achieve the goals of reform. We briefly describe how each variant would work, and discuss the economically important differences between them.

\section{A.1 Subordinated share class}

For every $\$ 1$ of MMF 2a-7 assets, the MMF would issue $\$ K$ of subordinated shares. Ordinary MMF shareholders would have the option to redeem on a daily basis at a \$1.00 NAV. Thus, ordinary shares would be open-ended mutual fund shares exactly as they are today. Subordinated shareholders would not have the right to redeem on demand. Instead, subordinate shares would closed-end, perpetual shares with a floating dividend tied to portfolio credit losses. These subordinated shares could either be held by the fund sponsor or by third-party investors. ${ }^{25}$

MMFs would need to define a priority rule that allocates credit losses between ordinary MMF shares and subordinated shares. Specifically, one can think of this as specifying a transfer $t=t\left(L_{A}\right)$ where $t$ is a decreasing function of portfolio losses, $L_{A}$. If the total return on portfolio assets is $R_{A}$ and credit losses are $L_{A}$, ordinary MMF shares would earn a dividend of $R_{A}-t\left(L_{A}\right)$ and subordinate shareholders would earn a dividend of $R_{A}+t\left(L_{A}\right) \times(1-K) / K .{ }^{26}$ As a result, the subordinate shares would earn a higher return in good times in exchange for agreeing to absorb a disproportionate share of portfolio losses in bad times. The ordinary shares would be even safer and would correspondingly earn a slightly smaller return.

Example: Suppose $K=4 \%$ and that $t=0.05 \%$ in normal times and $t=-R_{A} K /(1-K)$ in bad times when the portfolio of $2 \mathrm{a}-7$ assets suffers a credit loss. In this example, ordinary MMF shareholders would receive a yield of $R_{A}-0.05 \%<R_{A}$ in normal times and a yield of $R_{A} /(1-K)=1.04 \times R_{A}$ in bad times. Conversely, subordinated shareholders would receive a yield of $R_{A}+1.20 \%$ in normal times and a yield of $0 \%$ in bad times.

One technical question is how this structure would work dynamically. As above, the guiding analogy would be with open-ended bank deposits and closed-end bank equity. Suppose an MMF

\footnotetext{
${ }^{25}$ In the case where subordinate shares are held by third-party investors, they would be closed-end mutual fund shares. Investors would be allowed to buy and sell subordinated shares in the secondary market. Thus, there would be a near perfect analogy with open-ended bank deposits and closed-end bank equity.

26 Thus, we have $(1-K) \times\left(R_{A}-t\left(L_{A}\right)\right)+K \times\left(R_{A}+t\left(L_{A}\right) \times(1-K) / K\right)=R_{A}$, so that the weighted average dividend to ordinary and subordinated shares equals the return on the underlying assets. Technically, we would also require that $-R_{A} K /(1-K) \leq t\left(L_{A}\right)$ so that dividend payments to subordinated shareholders are non-negative.
} 
starts with $\$(1-K)$ of ordinary shares and $\$ K$ of subordinate shares. In this first period, payouts would be given by $(1-K) \times\left(R_{A}-t\left(L_{A}\right)\right)+K \times\left(R_{A}+t\left(L_{A}\right) \times(1-K) / K\right)=R_{A}$. Suppose there is an outflow of ordinary MMF shares so that there only $\$ N<\$(1-K)$ of ordinary shares. The ordinary shares would still receive $R_{A}-t\left(L_{A}\right)$, but subordinate shares would now only receive $R_{A}+t\left(L_{A}\right) N / K<R_{A}+t\left(L_{A}\right) \times(1-K) / K$. Clearly, we can always operate this rule as $N$ moves up and down since $N \times\left(R_{A}-t\left(L_{A}\right)\right)+K \times\left(R_{A}+t\left(L_{A}\right) N / K\right)=(N+K) \times R_{A}$. However, to satisfy the capital requirement, MMFs would need to raise more subordinate shares following significant inflows into ordinary open-ended shares. Specifically, following an inflow into ordinary shares, an MMF would be required to raise additional money by selling new closed-end subordinated shares and these new funds would be invested in $2 \mathrm{a}-7$ eligible assets. ${ }^{27}$

\section{A.2 Standby liquidity facility or escrow account}

MMFs would pay a premium for a standby liquidity facility whereby the MMF can sell some fraction of its portfolio at par when those assets become impaired. This liquidity facility could either be purchased from a fund sponsor or from a third-party insurer so long as the sponsor or third-party meets a regulatory standard for creditworthiness and liquidity. And the liquidity facility provider should have to hold an appropriate amount of equity capital against this commitment. ${ }^{28}$ Alternately, this standby facility should itself be backed by a dedicated buffer of highly liquid assets such as Treasury-bills that can be sold at a moment's notice in order to finance the purchase of impaired assets from the MMF.

For every $\$ 1$ of $2 \mathrm{a}-7$ eligible assets and $\$ 1$ of MMF shares the MMF would need to have access to $\$ X=\$ K /(1-K)$ in standby liquidity facilities. Here the facility a state-contingent net payment stream (premium minus policy payouts) of $t=t\left(L_{A}\right)$ so that the MMF shareholders receive a net yield of $R_{A}-t\left(L_{A}\right)$ and the facility provider would receive a net payment of $t\left(L_{A}\right)$.

\section{B. Comparison between types of capital}

Obviously, at high level, there is a strong correspondence between subordinated shares and standby liquidity facility. In either case, one has purchased a put against MMF assets from either the MMF sponsor or a third party. In return for this put, MMF shareholders will receive a slightly smaller return than they otherwise would in normal times in exchange for the additional safety this put offers in bad times.

\section{Mechanics of Recapitalization}

What should happen when an MMF suffers a credit loss and its capital buffer falls below the required minimum? Existing proposals, including the FSOC's capital buffer proposal, adopt the "prompt corrective action" approach from traditional banking regulation. Specifically, a MMF whose capital buffer fell below the required minimum would be immediately required to restrict its new investments to cash and Treasuries until its capital buffer was restored to the minimum ratio of

\footnotetext{
27 This could be done by "tapping" an outstanding series of subordinated shares trading at a premium or discount to "par value" or by issuing a new series of subordinated shares with a coupon set at the current market-going rate.

${ }^{28}$ Otherwise, one would worry that the liquidity provider would not be able to honor its commitment in a crisis, or that in so honoring its commitment the liquidity provider would exhaust in non-dedicated buffer of liquid assets or its capital buffer, thus comprising its own ability to engage in credit intermediation.
} 
risk-weighted assets. ${ }^{29}$ While there is little problem with this approach when a single MMF suffers an idiosyncratic loss, serious problems arise when many MMFs suffer a credit loss at the same time-e.g., due to a default by a major money-market issuer. In the latter case, this would discourage MMFs from drawing down on their capital buffers precisely when they should be encouraged to do so from a system-wide perspective. From a macro-prudential point of view, the primary purpose of MMF capital buffers is to allow MMFs to sustain a modest loss without triggering a widespread run on MMFs - a run that in turn leads MMFs to withdraw short-term funding from large financial firms. This "prompt correct action" approach would indirectly bring about the very outcome - a destabilizing withdrawal of funding from large financial firms - policy seeks to avoid in the first place. Instead, following a system-wide event when multiple MMFs suffer a loss, it would be desirable to allow MMFs to gradually rebuild their capital buffers - preferably by raising new junior capital. ${ }^{30}$

\section{Appendix B: Calibrating the Size of MMF Capital Buffers}

In this Appendix, we use a simple model of credit portfolio losses to calibrate the size of MMF capital requirements. Specifically, we adopt the workhorse Vasicek (2002) model of portfolio loss. The Vasicek model is simply a tool for translating the common sense insights of modern portfolio theory into the credit portfolio context where losses on individual positions tend to be binary in nature. Given the central role it plays in the Basel II bank capital framework (Gordy (2003)), the Vasicek model has the convenient feature of being well understood by private risk managers, policymakers, and academics alike.

\section{A. Analytical framework}

Assume that the return on assets for each obligor $i$ in a credit portfolio is

$$
r_{i}^{A}=\sqrt{\rho} f+\sqrt{1-\rho} \varepsilon_{i}
$$

where $f \sim N(0,1)$ is a common economic factor affecting all obligors in the portfolio and $\varepsilon_{i} \sim N(0,1)$ captures idiosyncratic obligor-specific factors-i.e., we assume $\operatorname{Cov}\left[\varepsilon_{i}, \varepsilon_{j}\right]=0$ for $i \neq j$. Thus, we have $r_{i}^{A} \sim N(0,1)$ and $\operatorname{Corr}\left[r_{i}^{A}, r_{j}^{A}\right]=\rho$ for $i \neq j$.

Assume each obligor defaults with probability $\pi$. Specifically, obligor $i$ defaults if $r_{i}^{A}<\Phi^{-1}(\pi)$. Letting $D_{i}=\mathbf{1}\left\{r_{i}^{A}<\Phi^{-1}(\pi)\right\}$ be a default indicator for obligor $i$, we have

$$
E\left[D_{i}\right]=\operatorname{Pr}\left[r_{i}^{A}<\Phi^{-1}(\pi)\right]=\pi .
$$

This implies that the default correlation between any pair of distinct firms $i$ and $j$ is

$$
\rho^{*}=\frac{\Phi_{2}\left[\Phi^{-1}(\pi), \Phi^{-1}(\pi), \rho\right]-\pi^{2}}{\pi(1-\pi)}
$$

\footnotetext{
${ }^{29}$ See FSOC (2012), p. 39. By only making new investments in 0\% risk-weight cash and Treasuries, an MMF's riskweighted assets would decline, thus raising its ratio of capital to risk-weighted assets.

${ }^{30}$ See Hanson, Kashyap, and Stein (2011), which makes a similar argument about bank capital regulation.
} 
where $\Phi_{2}[\cdot, \cdot, \cdot]$ denotes the standard bivariate normal cumulative distribution function. For instance, assuming $\pi=0.03 \%$ and $\rho=0.50$, equation (3) implies that the default correlation is $3.45 \%$.

Consider a credit portfolio of $N$ obligors each with portfolio weight $1 / N$. Assume the lossgiven-default for each obligor is $\lambda \in(0,1]$. Thus, the realized portfolio loss is given by

$$
L_{N}=\lambda \times N^{-1} \sum_{i=1}^{N} D_{i}
$$

Obviously, the expected portfolio credit loss is given by $E\left[L_{N}\right]=\lambda \pi$. Since the each firm's default is a binary outcome, the variance of portfolio loss is

$$
\operatorname{Var}\left[L_{N}\right]=\lambda^{2} \pi(1-\pi)\left(\frac{N+N(N-1) \rho^{*}}{N^{2}}\right)=\lambda^{2} \pi(1-\pi)\left(\rho^{*}+\frac{\left(1-\rho^{*}\right)}{N}\right),
$$

which is decreasing in the number of obligors in the portfolio, $N$. As the number of obligors increases, idiosyncratic default risk is diversified away, meaning that the portfolio only reflects systematic default risk. For instance, assuming $\lambda=1, \pi=0.03 \%$, and $\rho=0.50$, we have $\sqrt{\operatorname{Var}\left[L_{40}\right]}=0.40 \%$ and $\sqrt{\operatorname{Var}\left[L_{\infty}\right]}=0.32 \%$. As discussed below, higher moments and quantiles of the loss distribution for small $N$ can be obtained via simulation. ${ }^{31}$

We can derive convenient analytical expressions for the portfolio loss distribution in the limiting case where the number of obligors $N$ grows large. To derive the limiting distribution, we condition on the realization of the common factor linking firm returns, $f$. Specifically, we have

$$
E\left[D_{i} \mid f\right]=\operatorname{Pr}\left[r_{i}^{A}<\Phi^{-1}(\pi) \mid f\right]=\operatorname{Pr}\left[\varepsilon_{i}<\frac{\Phi^{-1}(\pi)-\sqrt{\rho} f}{\sqrt{1-\rho}} \mid f\right]=\Phi\left(\frac{\Phi^{-1}(\pi)-\sqrt{\rho} f}{\sqrt{1-\rho}}\right) .
$$

Equation (6) shows that the conditional probability of default is decreasing in the realization of the common factor, $f-$ i.e., firm default is less likely in good times when $f$ takes on higher values. As the number of obligors in the portfolio becomes arbitrarily large, the law of large numbers then implies that portfolio losses are almost surely equal to

$$
L_{\infty}=\lambda \times \Phi\left(\frac{\Phi^{-1}(\pi)-\sqrt{\rho} f}{\sqrt{1-\rho}}\right),
$$

when the realization of the common factor is $f$. Using equation (7), we can then derive the cumulative distribution of portfolio losses as

$$
\operatorname{Pr}\left[L_{\infty}<\ell\right]=\operatorname{Pr}\left[f>\frac{\Phi^{-1}(\pi)-\sqrt{1-\rho} \Phi^{-1}(\ell / \lambda)}{\sqrt{\rho}}\right]=\Phi\left(\frac{\sqrt{1-\rho} \Phi^{-1}(\ell / \lambda)-\Phi^{-1}(\pi)}{\sqrt{\rho}}\right) .
$$

Finally, using equation (8) we can solve for the $p^{\text {th }}$ percentile of the loss distribution-i.e., the value $K(p)$ such that $\operatorname{Pr}\left[L_{\infty}<K(p)\right]=p$. Specifically, we have

\footnotetext{
${ }^{31}$ A slight generalization of this result to a portfolio with a non-homogenous set of obligors weights, $\left\{w_{i}\right\}_{i=1}^{N}$, is $\operatorname{Var}\left[L_{N}\right]=\lambda^{2} \pi(1-\pi)\left(\rho^{*}+\left(1-\rho^{*}\right) \sum_{i=1}^{N} w_{i}^{2}\right)$. In other words, the granularity add-on is proportional to the Herfindahl index of portfolio weights. In the case of an equal-weighted portfolio, the Herfindahl is simply $1 / N$.
} 


$$
K(p)=\lambda \times \Phi\left(\frac{\sqrt{\rho} \Phi^{-1}(p)+\Phi^{-1}(\pi)}{\sqrt{1-\rho}}\right) .
$$

Naturally, equation (9) is increasing in $p, \pi, \lambda$, and $\rho$. One would set the size of the capital buffer using equation (9) for some value such as $p=99.9 \%$ set by policymakers-i.e., policymakers would choose a capital buffer such that the probability that an MMF breaks the buck is less than $0.1 \%$.

\section{B. Calibrating the capital requirement}

We now calibrate the capital requirement for unsecured corporate exposures. We first impose the simplifying assumption that the number of borrowers in the portfolio, $N$, is large. We revisit this concentration assumption below. We use the following inputs in our calibration:

- Loss-given-default, $\lambda=1$. There is a strong rationale for assuming $\lambda=1$ on MMF claims against unsecured paper. Studies suggest that loss-given-default has historically been higher for defaults on the financial debt that dominate MMF portfolios than for non-financial bonds (Altman and Kishore (1996)). Indeed, the loss-given-default in the recent Lehman Brothers and Icelandic bank defaults was over 90\%. Irrespective of the actual loss-given default, it is likely that highly risk averse MMF shareholders are and likely to react to portfolio defaults under a 100\% loss-given-default assumption (Duffie (2010)). Since the systemic risk posed by MMF losses has to do with the reaction of MMF investors, we believe that $\lambda=1$ is an appropriately conservative assumption.

- Asset correlation, $\rho=0.50$. The average pairwise correlation between any two stocks in the US is roughly 0.25 . However, since the vast majority of MMF obligors are financial firms, they are likely to be far more correlated with each other. Thus, there is a strong argument for assuming a higher asset correlation when calibrating MMF capital requirements. One simple approach to estimating this correlation is to examine the average pairwise correlation between the unlevered stock returns of financial firms. Doing so, our estimates of the average pairwise correlation between the unlevered stock returns of financial firms is roughly $\rho=0.50$. And, this is significantly higher than the average pairwise correlation between all corporations which we estimate to be roughly $0.25 .^{32,33}$

- Annual probability of obligor default, $\pi=0.03 \%$. The minimum annual probability of default for corporate issuers under Basel II is 0.03\% (see BCBS (2006)). As shown in Table 2, this $0.03 \%$ probability is in-line with Moody's (2010) estimates of the

\footnotetext{
${ }^{32}$ Suppose that $\bar{r}^{A}=\sqrt{\rho} f$ is the return on assets for a large equal weighted portfolio of financial firms. Since $\operatorname{Corr}\left(r_{i}^{A}, \bar{r}^{A}\right)=\sqrt{\rho}$, one way to estimate the average pairwise correlation is to look at the the average of the $R^{2}$ statistic from regressions on $r_{i}^{A}$ on $\bar{r}^{A}$. To implement this idea, we compute $r_{i}^{A}=(E /(E+D)) r_{i}^{E}$ where $E$ is the market value of equity, $r_{i}^{E}$ is the company's stock return, and $D$ is the book value of liabilities for all publicly-traded financial firms in the CRSP-Compustat sample. For each financial firm $i$, we then regress $r_{i}^{A}$ on the equal-weighted asset return for all financial firms, $\bar{r}^{A}$. Our estimate of $\rho$ is the average $R^{2}$ from these firm-level regressions.

${ }^{33}$ The estimated correlation of 0.25 for all firms is also in-line with the correlations assumed in pricing corporate CDOs.
} 
probability that a commercial paper with the highest short-term rating (i.e., P-1) defaults in the following year.

- Annual probability that an MMF does not "break the buck", $p=99.9 \%$ : This is not a parameter than can be estimated. Instead, this is an input that must be chosen by policymakers based on an assessment of (i) the costs of the financial instability that would be unleashed if an MMF "broke the buck" versus (ii) the costs, if any, of imposing higher capital requirements on MMFs. For simplicity, we use $p=99.9 \%$ which is the annual probability of bank survival adopted by policymakers under the Basel II Internal Risk-Based calibration (see BCBS (2006)).

Table 2: Commercial paper default probabilities: This table shows Moody's (2010) estimates of the probability of default on highly-rated (i.e., P-1 rated) commercial paper between 1972 and 2009 (see Exhibit 7 of Moody's (2010)). These probabilities are estimated at various daily horizons, $H$. We then convert these to an annual horizon (assuming time-series independence) using $P D(365)=1-(1-P D(H))^{365 / H}$. The annual $P D$ s implied from $P D$ s measured over longer horizons are larger since Moody's attempts to downgrade obligors, leading them to lose their P-1 rating, as they approach default.

\begin{tabular}{rrr}
\hline \hline Horizon in Days $(\boldsymbol{H})$ & Horizon $\boldsymbol{P D}(\boldsymbol{H})$ & Implied Annual $\boldsymbol{P D}(\mathbf{3 6 5})$ \\
\hline 30 & $0.003 \%$ & $0.036 \%$ \\
60 & $0.006 \%$ & $0.036 \%$ \\
90 & $0.009 \%$ & $0.036 \%$ \\
120 & $0.013 \%$ & $0.040 \%$ \\
180 & $0.021 \%$ & $0.043 \%$ \\
270 & $0.033 \%$ & $0.045 \%$ \\
365 & $0.045 \%$ & $0.045 \%$ \\
\hline
\end{tabular}

Using equation (9), these parameter values yield a capital requirement of $K=3.9 \%$. $^{34}$ Thus, this calibration exercise suggests that reasonable input values are consistent with a capital buffer in the neighborhood of the FSOC's recent 3\% and 4\% proposals.

Table 3: Required Capital Buffer for MMFs: This table shows the capital buffer needed to ensure that the probability that ordinary MMF shares sustain a loss is less than $0.1 \%$, assuming $\lambda=100 \%$.

\begin{tabular}{|c|c|c|c|c|c|c|}
\hline \multirow{6}{*}{ 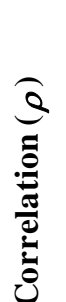 } & & \multicolumn{5}{|c|}{ Obligor Default Probability $(\pi), \%$ per annum } \\
\hline & & $0.01 \%$ & $0.02 \%$ & $0.03 \%$ & $0.04 \%$ & $0.05 \%$ \\
\hline & $30 \%$ & $0.77 \%$ & $1.36 \%$ & $1.88 \%$ & $2.36 \%$ & $2.81 \%$ \\
\hline & $40 \%$ & $1.14 \%$ & $2.03 \%$ & $2.83 \%$ & $3.55 \%$ & $4.23 \%$ \\
\hline & $50 \%$ & $1.50 \%$ & $2.77 \%$ & $3.90 \%$ & $4.93 \%$ & $5.90 \%$ \\
\hline & $60 \%$ & $1.81 \%$ & $3.49 \%$ & $5.04 \%$ & $6.47 \%$ & $7.81 \%$ \\
\hline & $70 \%$ & $1.92 \%$ & $4.07 \%$ & $6.12 \%$ & $8.06 \%$ & $9.90 \%$ \\
\hline
\end{tabular}

Of course, one's answer to this calibration question will only be as good as one's assumptions about the relevant inputs. It is extremely difficult to estimate the inputs with great precision and reasonable people will disagree. Therefore, Table 3 presents the required capital buffer when we vary our assumption about the probability of obligor default $(\pi)$ and the correlation

\footnotetext{
34 Alternately, we can redo this analysis assuming a 30-day probability of default of $0.003 \%$, but now requiring a monthly probability of MMF survival of $99.9917 \%=(99.9 \%)^{(1 / 12)}$. This yields a required capital buffer of $2.8 \%$.
} 
between obligor asset returns $(\rho)$. Table 3 suggests that reasonable assumptions on $\pi$ and $\rho$ yield capital requirements between $2 \%$ and $6 \%$, with a central tendency of perhaps $3 \%$ to $4 \%$. Furthermore, equation (8) shows that the requirement is linear in the assumed loss-given-default, $\lambda$. Thus, holding all other parameters besides $\lambda$ at their baseline levels, we obtain capital requirements of $3.12 \%(=80 \% \times 3.90 \%)$ and $2.34 \%(=60 \% \times 3.90 \%)$ if we assume that $\lambda=80 \%$ and $\lambda=60 \%$, respectively. Note, however, that this is the capital that MMF would be required to hold against unsecured paper which would be assigned a 100\% risk weighting. For instance, commercial paper would receive a risk weight of $100 \%$ and Treasury bills would receive a $0 \%$ risk-weight.

It is worth contrasting this calibration with a back-of-the-envelope calibration for the C\&I portfolio of a typical banking firm-i.e., for exposures that receive a 100\% risk weight under Basel. As above, we require that $p=99.9 \%$. For a bank portfolio of C\&I loans, one might assume $\lambda=60 \%$ based on average corporate recovery rates, $\rho=25 \%$ due to more diverse set of firms in banking portfolios (and in line with the standard assumption in corporate CDO pricing), and $\pi=1 \%$ reflecting an average BB-rating of bank borrowers. These inputs yield $K=11.0 \%$ which is in line with current Basel capital requirements. Specifically, Basel III would require banks to hold 10.5\% total capital as a fraction of risk-weighted-assets. Thus, despite the fact that MMFs assets are far less risky than banks loans, MMFs would still require about half of the capital of banks because (i) loss-given-default on financial paper is likely to be high and (ii) because the default correlations are far higher than in a banking portfolio.

\section{Pricing subordinate MMF shares}

How risky would subordinate MMF shares be? Many criticisms of MMF capital requirements seem to assume that subordinated shares would be very risky and that investors would thus require substantial "equity-like" returns to hold subordinate MMF shares. However, this perspective runs counter to the common sense logic of Modigliani and Miller (1958) which forms the cornerstone of modern corporate finance. The combined risk of first-priority shares and subordinate shares is the same - and equal to the total risk of the underlying portfolio assetsirrespective of the mix between first-priority and subordinate shares. The Modigliani-Miller logic suggests that subordinate MMF shares would not be all that risky because they are claims - albeit subordinate ones - against safe 2-a7-eligible assets. And since total risk must always be conserved, Modigliani-Miller logic suggests that both subordinate shares and first-priority shares would become safer as one increased the fraction of portfolio assets financed with subordinate shares.

To illustrate the first point, i.e., that subordinate MMF shares would not be particularly risky, assume that the capital buffer has been set at $K(p)$ as in equation (9) and let $Q_{\infty}=\min \left\{L_{\infty} / K(p), 1\right\}$ denote the percentage loss on the subordinated capital. We can compute the probability that a subordinate capital provider will suffer a percentage capital loss greater than $q \%$ (for $q \leq 100 \%$ ), corresponding to a portfolio loss of $\ell=q K(p)$, using

$$
\operatorname{Pr}\left[Q_{\infty}>q\right]=1-\Phi\left(\frac{\sqrt{1-\rho} \Phi^{-1}(q K(p) / \lambda)-\Phi^{-1}(\pi)}{\sqrt{\rho}}\right) .
$$

Using equation (9), the probability that the holders of a 3.9\% subordinate tranche would lose more than $60 \%$ of their capital is approximately $0.21 \%$. A $60 \%$ loss on the subordinated tranche is in-line 
with the average loss-given-default in corporate bonds and, thus, might loosely correspond to an "economic default" on the subordinated shares. ${ }^{35}$ Table 4 uses equation (9) to compute the probability that holders of a $3.9 \%$ subordinated tranche would realize a range of alternative percentage capital losses.

Table 4: Probability of various losses on a subordinated tranche: Using equation (9), we compute the probability that holders of subordinated shares suffer various percentage losses, $q$. We assume $\lambda=1, \pi=0.03 \%, \rho=0.50$, and $p=99.9 \%$, so the subordinate tranche has thickness $K=3.9 \%$.

\begin{tabular}{ccc}
\hline \hline $\begin{array}{c}\text { Loss on } \\
\text { Subordinated Capital }\end{array}$ & $\begin{array}{c}\text { Corresponding Total } \\
\text { Portfolio Loss }\end{array}$ & $\begin{array}{c}\text { Probability of Loss on } \\
\text { Subordinated Capital }\end{array}$ \\
\hline $20 \%$ & $0.78 \%$ & $0.75 \%$ \\
$40 \%$ & $1.56 \%$ & $0.35 \%$ \\
$60 \%$ & $2.34 \%$ & $0.21 \%$ \\
$80 \%$ & $3.12 \%$ & $0.14 \%$ \\
$100 \%$ & $3.90 \%$ & $0.10 \%$ \\
\hline \hline
\end{tabular}

By way of comparison, Table 5 lists Moody's (2012) estimates that the annual probability of default and loss-given-default for corporate bonds of various credit ratings from 1920-2011. Thus, Table 5 suggests that the probability that a MMF subordinated capital provider would suffer a $60 \%$ loss of capital is in-line with default probability — and hence a $60 \%$ loss of capital — for a low investment grade corporate bonds, e.g., A-rated or BBB-rated bonds.

Table 5: Corporate default probabilities and loss-given default by credit rating: This table shows Moody's (2012) estimates of the annual probability of default and loss-given default on corporate bonds of various ratings. Default probabilities are from Exhibit 26 of Moody's (2012) and loss-given-default is one minus the 1-year recovery rate on unsecured exposures from Exhibit 21 of Moody's (2012).

\begin{tabular}{ccc}
\hline \hline Bond & $\begin{array}{c}\text { Default Probability, } \\
\text { Rating }\end{array}$ & $\begin{array}{c}\text { Loss-Given Default, } \\
\mathbf{1 9 8 2 - 2 0 1 1}\end{array}$ \\
\hline AAA & $0.00 \%$ & N/A \\
AA & $0.07 \%$ & $62.76 \%$ \\
A & $0.10 \%$ & $68.23 \%$ \\
BBB & $0.28 \%$ & $58.61 \%$ \\
BB & $1.27 \%$ & $52.89 \%$ \\
B & $3.67 \%$ & $62.12 \%$ \\
CCC & $11.97 \%$ & $64.28 \%$ \\
CC-C & $24.05 \%$ & $62.21 \%$ \\
\hline \hline
\end{tabular}

What would be a reasonable market-based estimate of the credit spread that investors would demand for bearing the risk inherent in subordinate MMF shares? To get a rough sense of the likely credit spread, in Table 6 we examine data on the average 5-year generic bonds spreads over LIBOR from 1994-2012 using data from Barclay's Capital.

As noted by Coval, Jurek, and Stafford (2009), investors should not care simply about expected credit losses. Investors should also care about the systematic risk reflected in those credit losses - i.e., the tendency for losses to occur in bad economic times when losses on other financial

${ }^{35}$ One might loosely associate smaller losses on subordinate MMF shares with transitions to lower, non-default corporate bond ratings - e.g. a transition from BBB to B. 
assets are also high — and should charge a risk premium on bonds that tend to default in bad times. This logic argues in favor of using financial spreads as opposed to spreads for all corporate bonds as a benchmark for subordinate MMF shares. Specifically, since financial firms own diversified portfolios of claims against others corporations, the idea is that losses on financial debt will tend to cluster in bad times. Thus, financial debt exposes investors to a higher amount of higher systematic risk than non-financial debt with comparable ratings and, hence, comparable expected losses.

Table 6: Corporate bond spreads (in basis points): This table shows corporate bonds spreads (on a swapped equivalent basis over LIBOR) from Barclay's Capital. We use monthly data on 5-year bonds spreads for all corporate bonds and corporate bonds by the subset of financial firms.

\begin{tabular}{lrrrr}
\hline \hline Rating, Sector & $\begin{array}{r}\text { Avg. Spread, } \\
\mathbf{5 / 9 4} \text { to 11/12 }\end{array}$ & $\begin{array}{r}\text { Avg. Spread, } \\
\mathbf{5 / 9 4} \text { to 12/07 }\end{array}$ & $\begin{array}{r}\text { Avg. Spread, } \\
\mathbf{1 / 0 8} \text { to 11/12 }\end{array}$ & $\begin{array}{r}\text { Current Spread, } \\
\mathbf{1 1 / 1 2}\end{array}$ \\
\hline AA-rated, All & 49.7 & 24.1 & 120.2 & 48.2 \\
AA-rated, Financial & 57.0 & 26.3 & 141.8 & 61.0 \\
A-rated, All & 70.0 & 42.0 & 147.5 & 70.1 \\
A-rated, Financial & 101.1 & 46.4 & 252.3 & 106.0 \\
BBB-rated, All & 126.0 & 79.6 & 254.1 & 139.0 \\
BBB-rated, Financial & 164.6 & 91.0 & 367.8 & 171.0 \\
BB-rated, All & 316.5 & 241.7 & 523.3 & 386.7 \\
BB-rated, Financial & 417.6 & 312.0 & 709.5 & 414.9 \\
\hline \hline
\end{tabular}

Table 6 suggests that a spread on subordinated shares in the neighborhood of 120 bps would be consistent with current market data. Seen in this light, claims by industry critics that investors would require returns on the order of $10 \%$ over the risk-free rate for holding subordinated MMF capital seem like quite a stretch. And given a 3.9\% capital requirement, this suggests that ordinary MMM shareholders would offer a yield that is approximately $4 \% \times 1.20 \% \div 96 \%=0.05 \%$ less than the underlying 2a-7 assets. Critically, one must recall that this reduction in yield is not a "loss" for ordinary MMF shareholders, but is simply a consequence of the normal positive relationship between risk and return. With the introduction of a subordinate share class, first-priority MMF shares will become even safer. And risk-averse MMF investors should therefore require a slightly smaller return for holding these shares. Of course, any investor who wants to accept more risk can buy both the first-priority and subordinate shares, enabling her to recover the risk of the underlying assets (i.e., 96.1\% first-priority shares and 3.9\% subordinate shares). However, a major benefit of a system with subordinate shares is that this makes it transparent that one cannot get something (more return) for nothing (no additional risk) as some MMF investors might be tempted to assume. ${ }^{36}$

\section{Adjusting the capital buffer for concentrated portfolios}

For simplicity, we calibrated the capital requirement using equation (9) which assumes that each obligor is only a tiny fraction of the underlying credit portfolio. This in turn implies that

\footnotetext{
${ }^{36}$ Here is another approach to estimating the cost of MMF capital that yields a similar number. Suppose the market beta on short-term debt issued by financial firms is 0.009 . For instance, if financial firms are leveraged 10 to 1 , have a asset beta of 0.1 , and an equity beta of 0.92 , then their debt beta is $0.009=(0.1-0.10 \times 0.92) / 0.90$. The assets of MMFs are simply this very low-risk debt. If there is enough MMF capital so that ordinary MMF shares are riskless, the market beta on MMF capital is $0.23(=0.009 / 0.04)$. Assuming a market risk-premium of $5 \%$, this implies that the expected excess return on MMF capital must be $1.13 \%$. Assume that MMF capital defaults with probability $0.20 \%$ and suffers a loss of $60 \%$. Then MMF capital must pay a coupon of $1.25 \%(=(1.13 \%+0.2 \% \times 60 \%) \div 99.8 \%)$ in normal times.
} 
idiosyncratic default risk has been completely diversified away, so the portfolio is only exposure to systematic default risk that is driven by the economy or market as a whole. Of course, real world MMF portfolios are not perfectly well diversified and remain exposed to some idiosyncratic default risk. Fortunately, the exact same issues arise when calibrating risk-based Basel II capital requirements for banks, so there is ample knowledge in both the regulatory and practitioner communities for dealing with these issues.

We now simulate the loan loss distribution in the case where $N$ is small. Specifically, in Table 7 where we compute the $99.9^{\text {th }}$ percentile of the loss distribution for various values of $N$. We use equation (3) to simulate portfolio losses. First, we first draw a value of the common economic factor, $f$. We then independently draw the idiosyncratic, obligor-specific component of returns $\varepsilon_{i}$ for each of the $N$ firms. We can then compute the firm default indicators and realized portfolio loss. In this way, we can derive the loss distribution for a portfolio with $N$ obligors.

Table 7: Required Capital for Concentrated Portfolios: This table reports the $99.9^{\text {th }}$ percentile of the loss distribution for various values of $N$. We simulate the portfolio loss distribution $L_{N}$ using 25,000,000 replications.

\begin{tabular}{cc}
\hline \hline $\mathbf{N}$ & $\boldsymbol{K ( 0 . 9 9 9 )}$ \\
\hline 25 & $8.00 \%$ \\
50 & $6.00 \%$ \\
75 & $4.00 \%$ \\
$\infty$ & $3.90 \%$ \\
\hline
\end{tabular}

Table 7 suggests that the appropriate granularity adjustment for MMF portfolios may be sizeable. For instance, a MMF portfolio of only 50 obligors would require a capital buffer of $6.00 \%$ in order to achieve the $0.1 \%$ probability of "breaking the buck" that a more diversified portfolio could achieve with $4.00 \%$ capital. Thus, as discussed in the main text, we propose that MMFs face a simple schedule such as that in Table 7 that would specific their required capital as a function of portfolio concentration. As discussed by Gordy (2003), a simple way to approximate the capital requirement for a non-equal-weighted portfolio of $N$ obligors is to impose the capital requirement that would be appropriate for an equivalent equal-weighted portfolio of $N^{*}$ obligors where $1 / N^{*}=\sum_{i=1}^{N} w_{i}^{2}$-i.e., one equates $1 / N^{*}$ with the portfolio Herfindahl index. Thus, funds would be subjected to requirements based on $N^{*}$ as opposed to the number of firms in their portfolio.

The portfolios of prime MMFs have historically been quite concentrated. Based on form NMFP data from August 2011 for non-government holdings, the average share of an obligor in an MMF portfolio is $2.7 \%$, the median is $2.4 \%$, the $10^{\text {th }}$ percentile is $1 \%$, and the $90^{\text {th }}$ percentile is close to the $5 \%$ limit. The mean Herfindahl index for non-government holdings is $5 \%$ (corresponding to $\left.N^{*}=20\right)$ and the median is $3.5 \%\left(N^{*}=29\right)$. Thus, assuming no change in MMF portfolios, the granularity add-ons could be quite substantial. ${ }^{37}$ However, the add-ons would fall substantially if MMFs reduced the concentration of the portfolios - a step that would enable them to meet the core objective of providing savers with a diversified portfolio of deposit-like instruments.

\footnotetext{
${ }^{37}$ In our NMFP data the average portfolio share of Treasuries and Agencies is $30 \%$, which would scale the overall capital down substantially: a $6 \%$ capital requirement on risky assets is a $4.2 \%$ capital requirement on total assets.
} 